\title{
RePLITO
}

\section{Nari Shakti and the Nation : Visual Imagery and Mediation of 'India's New Daughters' in the Framework of Muscular Patriotism}

\author{
Nadja-Christina Schneider
}

Published on: Mar 03, 2022

DOI: $10.21428 / f 4 c 6 e 600 . e f c 48099$

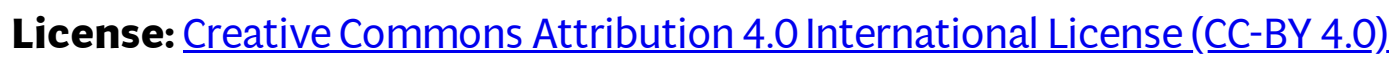




\begin{abstract}
For the last three decades, women seeking to engage in the political project of muscular (Hindu) nationalism could take either the role of the 'heroic Hindu mother' or of the 'sadhavi (celibate) warrior'. Muscular nationalism as a concept has been taken up by Sikata Banerjee [Banerjee 2003, 2005, 2010] and adapted to India's changing political landscape of the 1990s and 2000s. However, it seems equally relevant for a contemporary context in which the BJP government under Prime Minister Narendra Modi has recently conceptualized a third role which is specifically reserved for young unmarried women: the 'new daughters' of the Indian state. Especially the physically trained bodies of young women are imagined and visually represented as enabling them to 'defend' themselves - but also the 'body' of the national territory - against the violent attacks of an imagined Other, within as well as outside India. It is particularly striking that the 'new daughters of the nation' seem to be paradigmatically embodied and visually mediated through emerging symbolic figures such as the female athlete, police officer or Indian Air Force pilot.
\end{abstract}

These visual mediations of India's 'empowered daughters' are increasingly circulated across different media platforms and networks, ranging from global streaming services, such as Netflix or the Hindi film industry, to local print and online media. While some viewers may immediately associate these visualizations with a variety of globally circulating images of female air force pilots, others may also be reminded of earlier iconic examples of 'women in command' in South and Southeast Asia. Notably the Rani of Jhansi Regiment which was part of the Indian National Army (Azad Hind Fauj) led by Bengali revolutionary Subhas Chandra Bose during the Second World War. Some have even regarded this regiment as a model of empowerment for contemporary Indian women. Others, however, feel the need to revive the memory of 'forgotten histories' of the Azad Hind Fauj, and of the role women played in it, to corroborate the idea that, 'as history tells us', it will not be something new if women in India are finally given a far more active role in military formations.

Although it would perhaps be too easy to dismiss what seems to be a rather simplistic equation of 'empowerment' with 'physical power' as limited and limiting, it is precisely the language of an unmistakably patriarchal family ideology and 'fatherly' state which should raise doubts about the intention behind the BJP's new 'state-feminist' rhetoric. 1 As I argue in this article, the focus should thus not only be laid on the Indian Armed Forces, which are still perceived as a secular institution in India $\underline{2}$, but also on the 
discursive linkages and connections between this new brand of 'heroic patriots' and the preexisting involvement of women in the paramilitary Hindu nationalist organizations as well as their participation in the political project of muscular (Hindu) nationalism.

\section{Introduction}

On the $26^{\text {th }}$ of January in 2015, I attended the annual Republic Day Parade in Delhi for the second time in my life. Similar to other postcolonial states, such as Singapore for instance, the Republic Day Parade holds central symbolic importance in India. It

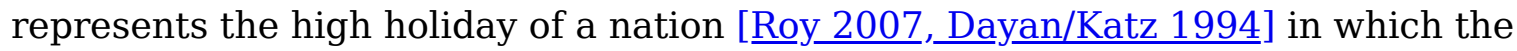
imagined identity and (proclaimed) integration and cohesion of the nation, based on its 'unity in diversity' [Mahajan 2019], is visually mediated and celebrated. Moreover, the Republic Day Parade offers the state an opportunity to demonstrate its military power. The proud presentation of state-of-the-art military technology, including tanks, missiles, helicopters, or loud fighter jet planes that shake you to the bone while dashing over thousands of observing heads, is an essential part of the show - and so are the marching contingents of the Indian Armed Forces.

As US president Barack Obama and his wife Michelle visited India and attended the festivities in Delhi on this rainy Monday in 2015, the $66^{\text {th }}$ Republic Day Parade was a particularly big deal in India. 


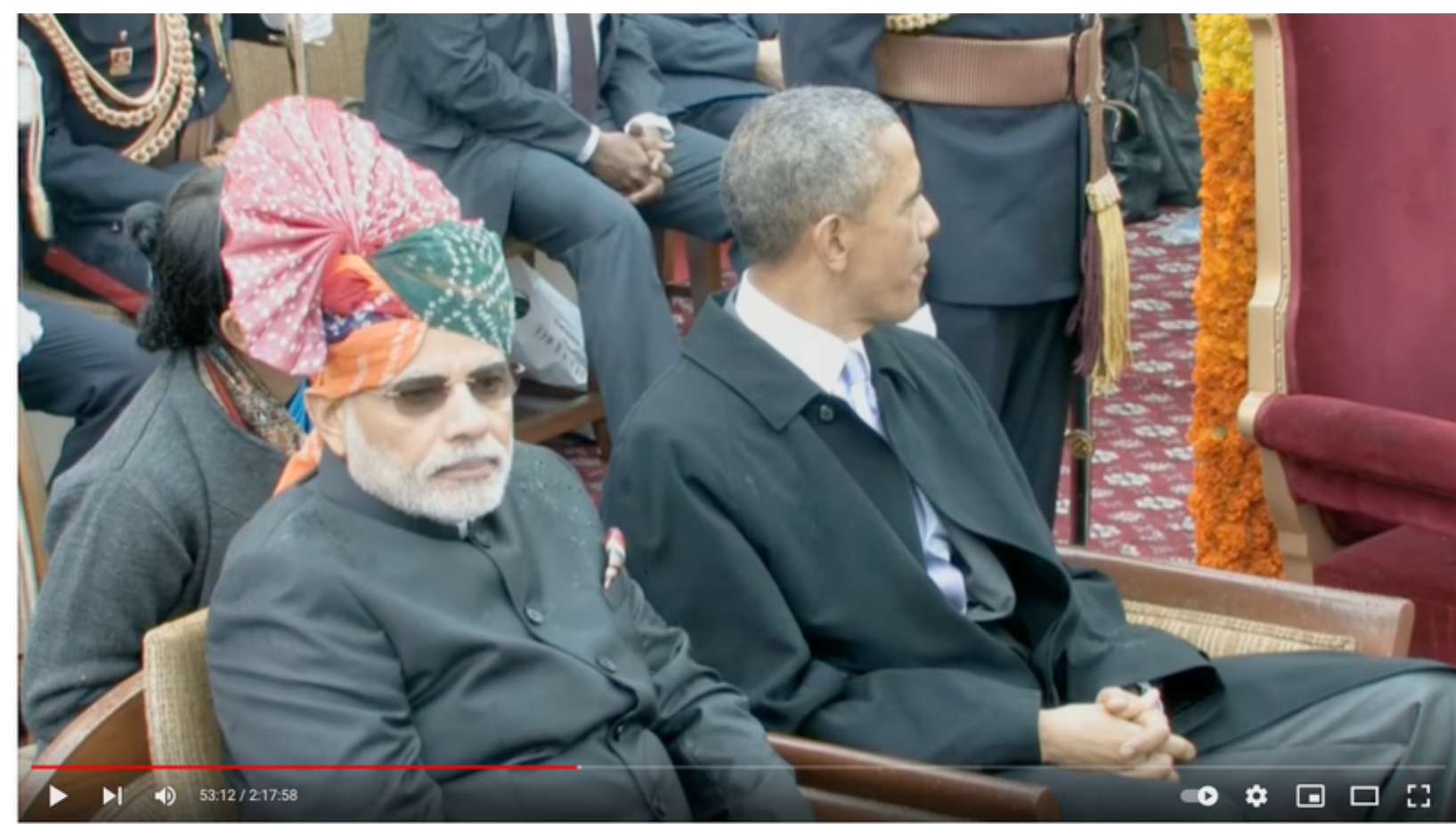

The 66th Republic Day 2015 Ceremony I PMO

Still from “The 66th Republic Day 2015”, published on the official Prime Minister's Office YouTube channel on Jan 26, 2015. https://www.youtube.com/watch? v=td8jc3uVPGk (last accessed Mar 17, 2022).

The Hindu nationalist party Bharatiya Janata Party (BJP) had just come to power in 2014, after a highly polarizing election campaign. To a large extend, the campaign had been based on the nationalist othering of and mobilization against Muslims and other marginalized communities in India; on the charismatic power and leadership skills that were ascribed to the former Chief Minister of the west Indian state of Gujarat, Narendra Modi, and, not least, on a transmedia masculinist imagery associated with Hinduism which had become increasingly widespread since the 1980s. Although a perceived 'crisis of masculinity' can be observed and is currently discussed globally $\underline{3}$, in the Indian context, the discourse has been decisively shaped by the colonial knowledge production and representation of the colonized as 'effeminate and feeble' as opposed to a portrayed ideal of 'British-Christian manliness'. The repercussions of this deep-seated insecurity are identified by several scholars as a main reason for a continued search for new role models as well as an Indian ideal of manliness and masculinity. In her book "Make Me a Man! Masculinity, Hinduism, and Nationalism in India" [Banerjee 2005], Sikata Banerjee provides an elaborate discussion of the 
colonial origin and longer history of the desire to "masculinize" Hinduism which ultimately led to a phenomenon that she describes as "muscular nationalism".

\section{Background: The BJP and the 'family' of Hindu nationalist organizations in India}

Formed in 1980, the Bharatiya Janata Party (BJP) is part of a network that includes a large number of cultural and religious-nationalist organizations, most notably the RSS (Rashtriya Swayamsevak Sangh), formed in 1925, and the VHP (Vishva Hindu Parishad), formed in 1964, but also trade unions, student organizations as well as various other associations, commonly called the sangh parivar ('family of organizations')[Berglund 2009]. Despite ideological differences among them they all represent some aspects of 'militant' Hindu nationalism. Another important feature are close inter-personal relations between their members [Banerjee 2003:168]. Several of these organizations have separate so-called women's wings, for instance, the Mahila Morcha (BJP), the Sadhavi Shakti Parishad (VHP), Durga Vahini (VHP) Rashtriya Sevika Samiti (RSS) or the Mahila Aghadi (the Shiv Sena Women's Front) which have all been very influential in redefining the (private and public) roles of Indian women in the last decades [Sarkar 1999, Basu 1999, Sarkar/Butalia 1995, Banerjee 2003, Sen 2019].

Perhaps the first thing that my family and I realized in the $66^{\text {th }}$ Republic Day Parade in January 2015 was the visual absence of federal states of the Indian union in which the BJP was not in power at that time. Usually, every federal state has its own appearance in the parade. But what really caught our attention was the careful staging of young women's achievements and leading roles in the spheres of science, competitive sports, the police and, most prominently, in the different sections of the Indian Armed Forces in this parade. Especially striking in this regard were a float by the Indian Railways (Bharatiya Rel) as well as one representing women soldiers of the Indian Armed Forces who had hoisted the Indian flag on the Mount Everest.

An anchor who moderated the event on television said that these "daredevil women have set an incredible and indelible mark of Nari Shakti". Nari Shakti literally means "woman power" and the BJP tried to popularize the term ever since the party came to power. Interestingly, the term was also selected by the Oxford Dictionaries as the 'Hindi Word of the Year' in 2018. 


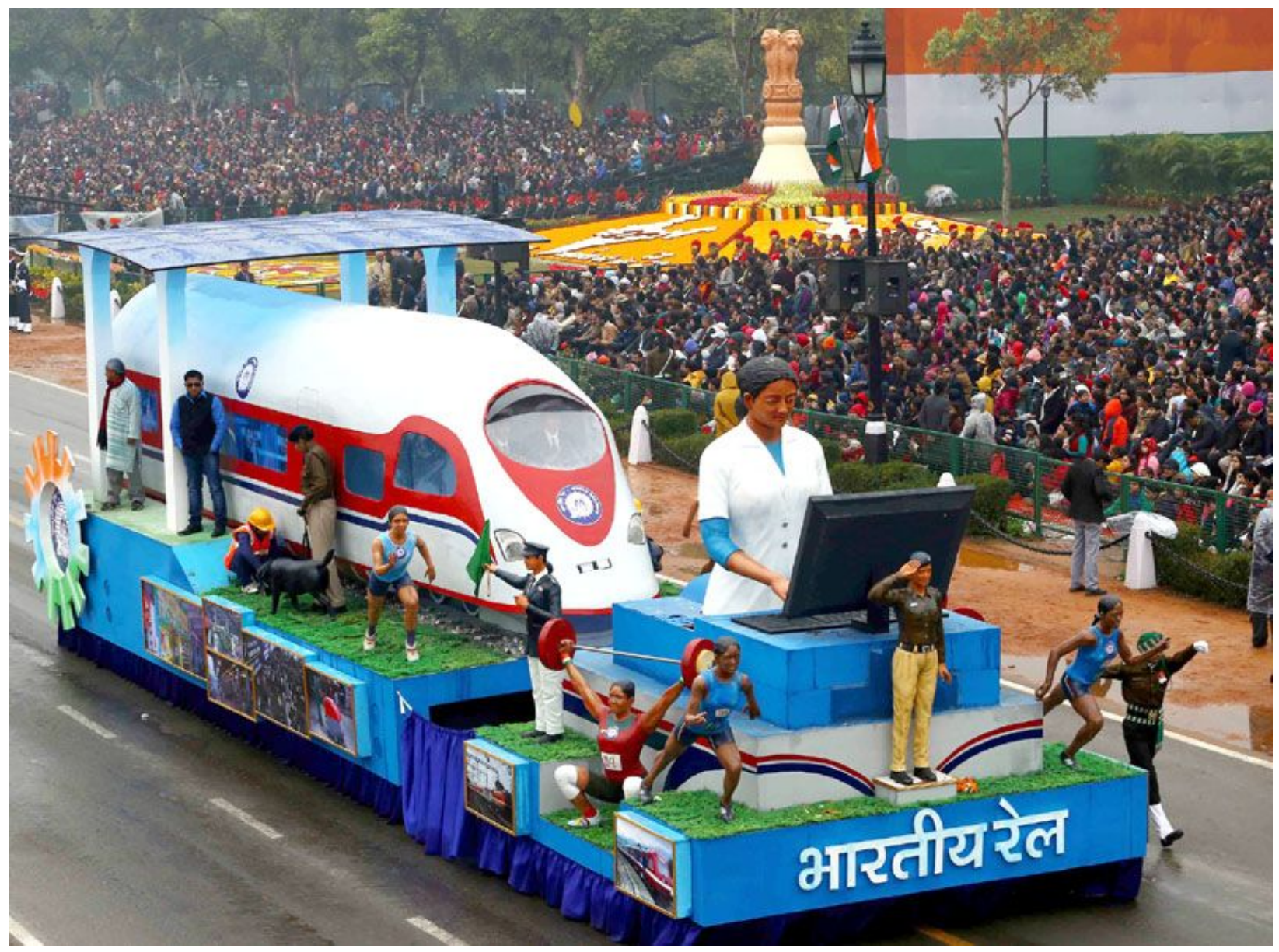

Image taken from the homepage of INDIAN BUREAUCRACY, BUREAUCRACY NEWS - SARKAR IMIRROR, published on Jan 26, 2015. https://www.sarkarimirror.com/thetableau-ministry-of-railways-passes-through-the-rajpath-during-the-66th-republicday-parade-2015-in-new-delhi/ (last accessed Mar 17, 2022). 
(The sign in Hindi includes the figure of the "woman warrior" who successfully climbed the Mount Everest into "India's Freedom Fighters".)

The same anchor got even more excited when for the first time at a Republic Day Parade in India, a contingent of women officers drawn from the Indian Army, Navy and Air Forces marched down the ceremonial boulevard called Rajpath. She described them as "sharp, impeccable and a visual treat of discipline, unity and valor lead by_ Captain Divya Ajith".
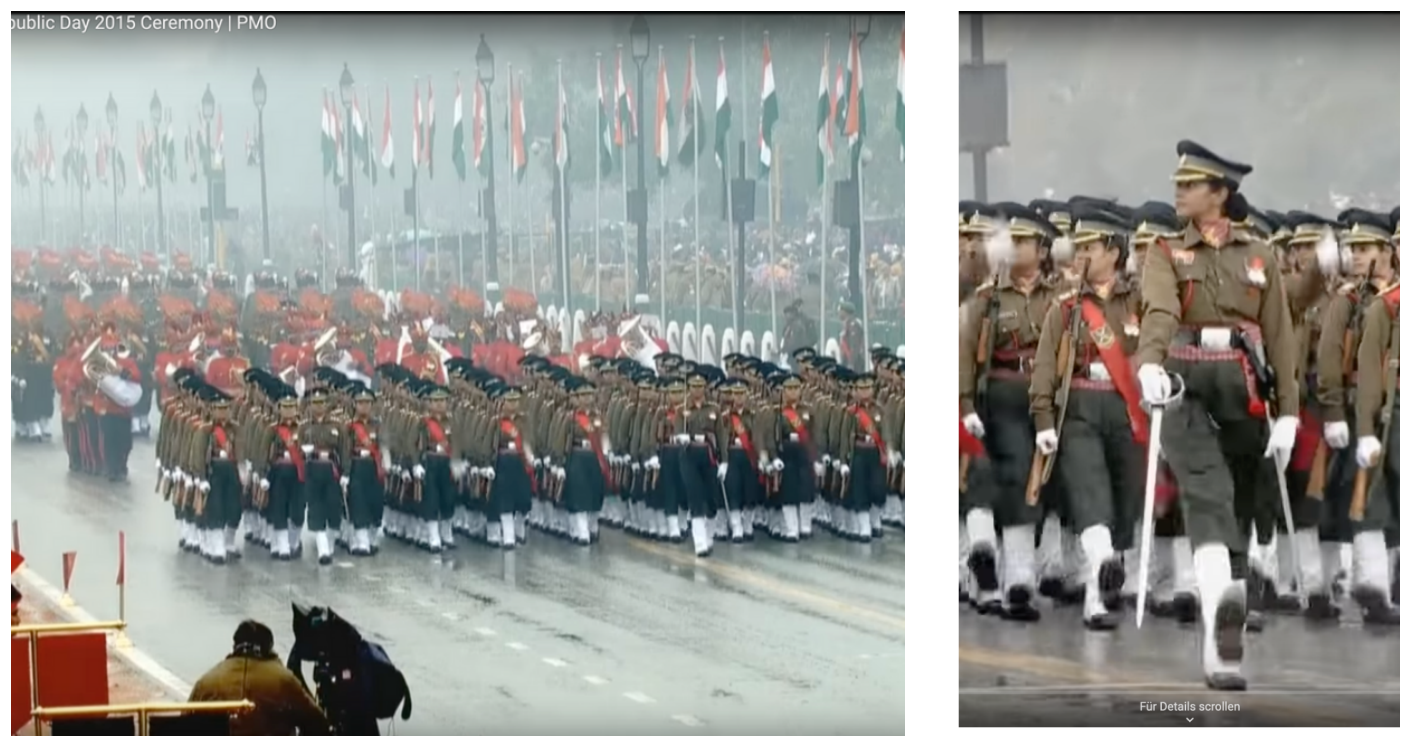

Stills from "The 66th Republic Day Ceremony", published on the official Prime Minister's Office YouTube channel on Jan 26, 2015. https://www.youtube.com/watch? $v=$ td8jc3uVPGk (last accessed Mar 17, 2022).

In the literature on women's participation in the political project of muscular nationalism, it is stressed that the "existence of multiple ways of mapping gender and militarism in India has, to a certain extent, enabled female visibility in the Hindu nationalist project"[Banerjee 2003: 169]. Indeed, throughout the 1990s and 2000s, more and more women from very different walks of life had successfully created a space within this process, "delicately negotiating their way through culturally dominant ideas of masculinity and femininity in ways that are powerful and visible"[Banerjee 2003: 168]. 
As historical and ethnographic research has shown, the two roles that enabled them to do so were the 'heroic mother' and the 'celibate warrior'.

\section{Women's participation in muscular Hindu nationalism as 'heroic mothers' and 'celibate warriors'}

The intersection of ideals of motherhood and women's role as mothers within nationalism as well as the nation-building process is of course not unique but perhaps particularly pronounced in India. As mothers, they can give birth to sons who will become the citizen soldiers ready to defend the nation, which is also imagined and addressed as a woman and mother. As primary caregivers of children, "heroic mothers" nurture and socialize future warriors by passing on culture, rituals, and nationalist myths to the next generation [Banerjee 2003:177]. The rhetoric and imagery of Hindu nationalist organizations is infused with references to this "Matri Shakti" ("mother's power"). $\underline{4}$ But as Rajani Rai has pointed out, the idea of motherhood has "vast dimensions and extends beyond the family to town, society, country and nation" [Rai 1996: 45]. So even without wanting to achieve power, if they wish to successfully transfer necessary skills to their children to shoulder any responsibility in life, especially in a rapidly globalizing country and changing socioeconomic context, as "commanders of the home", the mothers themselves first must become able administrators [Banerjee 2005: 119]. For example, that is how the the women's wing of a very influential organization called Rahstriya Swayamsevak Sangh (RSS), the Rashtriya Sevika Samiti, justifies their training program for women. This program includes physical training, long periods of absence from home, and units aimed at creating potent decision makers - hence, the creation of heroic, strong and efficient Hindu mothers who are nevertheless neither perceived as threatening to the landscape of muscular nationalism nor to the normative Hindu family which is seen as the foundation of the nation. 


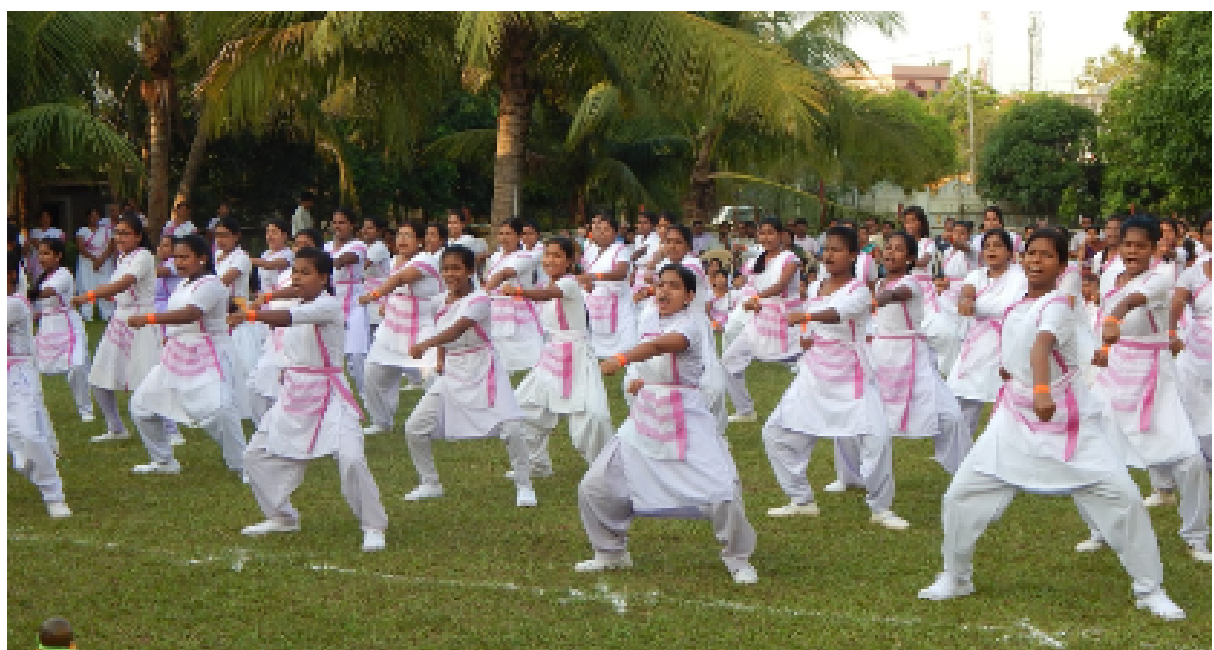

Image taken from the website of Vishwa Samvad Kendra (VSK Bharat), the official media center of the Rashtriya Swayamsevak Sangh (RSS). "Matrushakti and RSS - The Inspiring Saga of Rashtra Sevika Samiti".

https://vskbharat.com/matrushakti-and-rss-the-inspiringsaga-of-rashtra-sevika-samiti/?lang=en (last accessed Mar 17, 2022).

("Matrushakti and RSS: The Inspiring Saga of Rashtra Sevika Samiti”,_Oct 27,2018). 


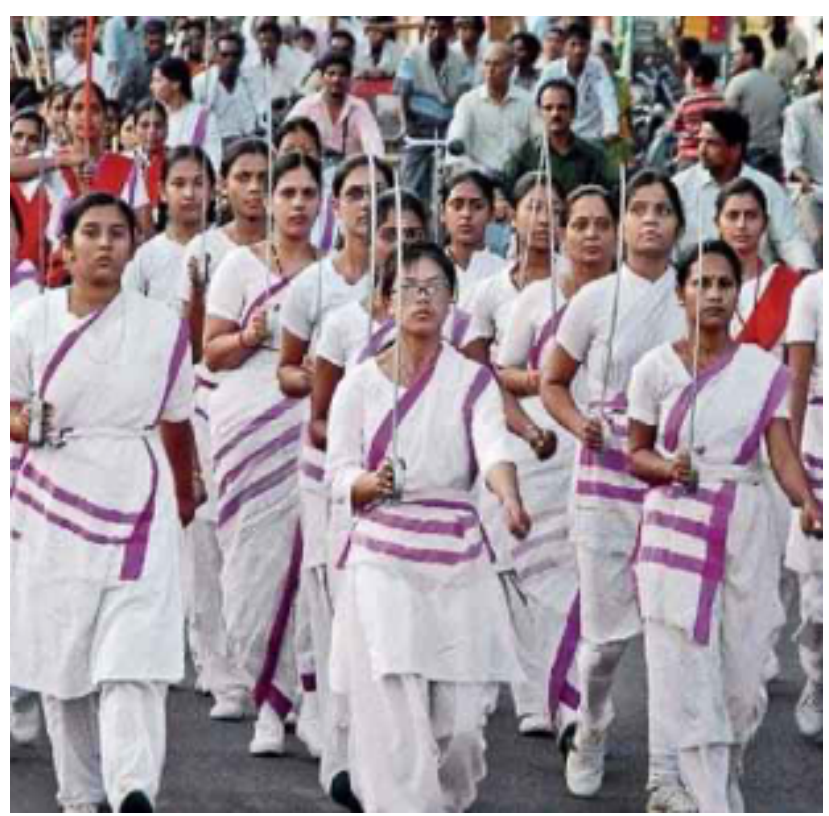

Image taken from the homepage of The Pioneer. "Rahul Gandhi's misinformed jibe”, by Ajay Bhardwaj. Oct 27, 2017. https://www.dailypioneer.com/2017/colu mnists/rahul-gandhis-misinformedjibe.html (last checked Mar 17, 2022). 


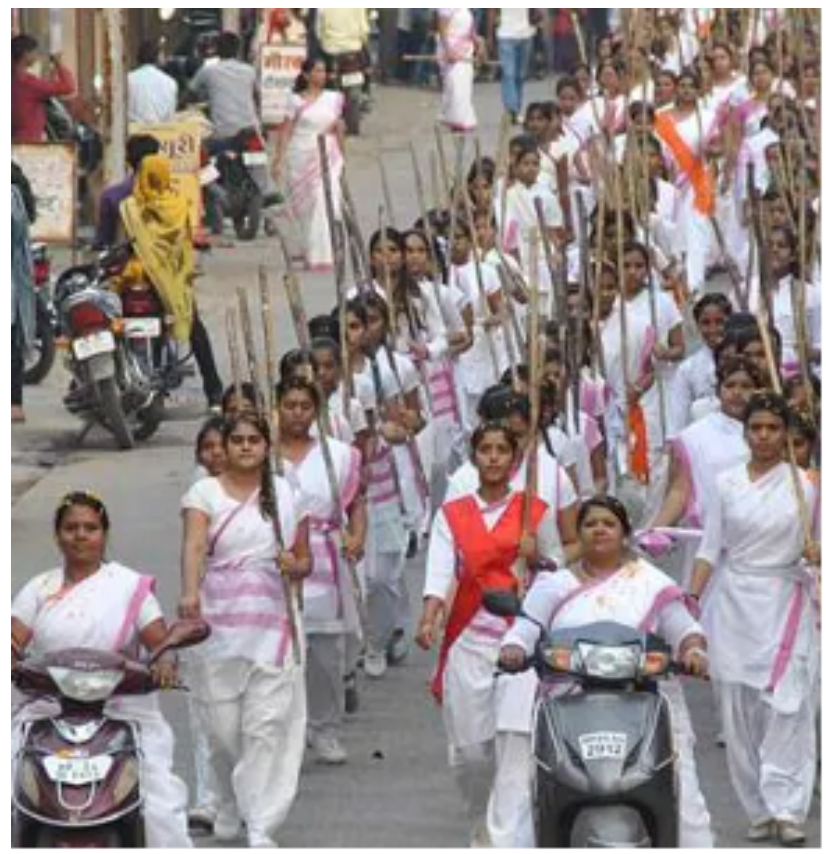

Image taken from the website of

Hindustan Times. "At home and work,

RSS has a model for the new-age

woman". Dec 08, 2016.

https://www.hindustantimes.com/india-

news/rss-empowers-women-within-the-

context-of-family-and-the-nation/story-

jcuQntOF1mZzmkdINFfIrJ.html (last

accessed Mar 17, 2022).

("Contrary to mainstream notions of feminism, the Rashtra Sevika Samiti empowers its members within the context of the family and the nation", HT, Dec 08, 2016)

A second possibility to participate in the ever-expanding Hindu nationalist project without risking censure or sanction from an overwhelmingly male elite leading the project of masculinization of the nation - which became more prominent in the 1990s and 2000s was to take on 'masculine' traits or the role of a sadhavi. The sadhavi is the female counterpart of the male sadhu, who, in the Hindu's world view, has renounced a worldly life to search for personal salvation and enlightenment. It is very clear that women can also make strategic use of these available roles and platforms to escape prescribed normative gender roles, while at the same time nevertheless propagating the heteronormative Hindu family and centrality of motherhood. Hence, the critique is never openly expressed nor are attempts being made at creating acceptance for the diversity of lives and identities of women. Accordingly, these individual acts of 
'transgression' or 'resistance within tradition' do not aim at challenging or changing the patriarchal gender order nor do they critically reflect on the patriarchal violence inherent in the ideology they subscribe to [see Basu 1999; Sarkar and Butalia 1995].

Prachi Trivedi is one example of a "celibate warrior" who actually is a "female foot soldier" in a militant Hindu nationalist organization called Durga Vahini, the women's wing of the Vishva Hindu Parishad (VHP). She is one of the lead characters in Nisha Pahuja's well-known documentary The World Before Her (2012) $\underline{5}$. Shooting her film in India, Pahuja had the opportunity to film at the Durga Vahini $\underline{6}$ camp. Prachi Trivedi, who comes from an upper caste Brahmin family in Nagpur, Maharashtra, was 24 years old at the time. Because of her father's allegiances with the organization, Trivedi started attending the camps conducted by Durga Vahini since she was three years old and eventually graduated to a trainer for the younger participants of the camp, herself being trained in various forms of combat and well versed in the organization's ideological claims about women, nation, and minorities; she has also very actively propagated violence against Muslims.

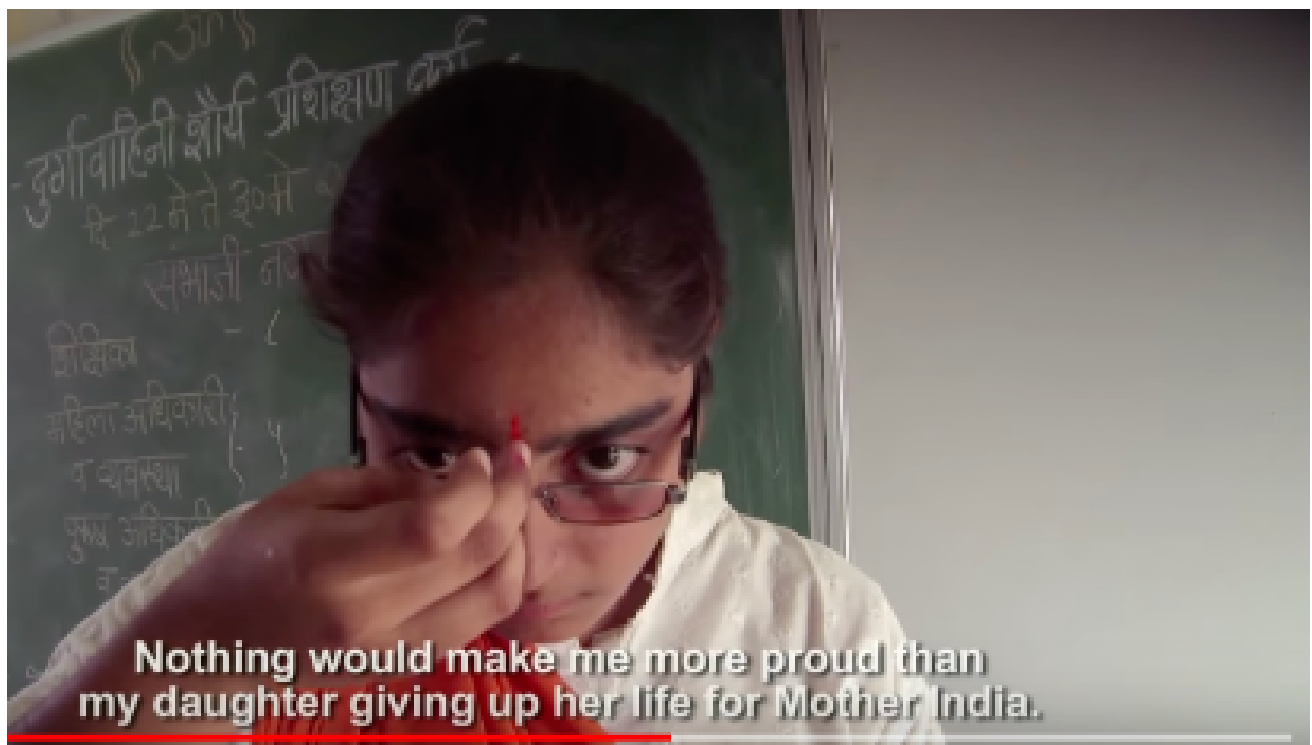

Still from the film "The World Before Her". Dir. Nisha Pahuja (2012). 


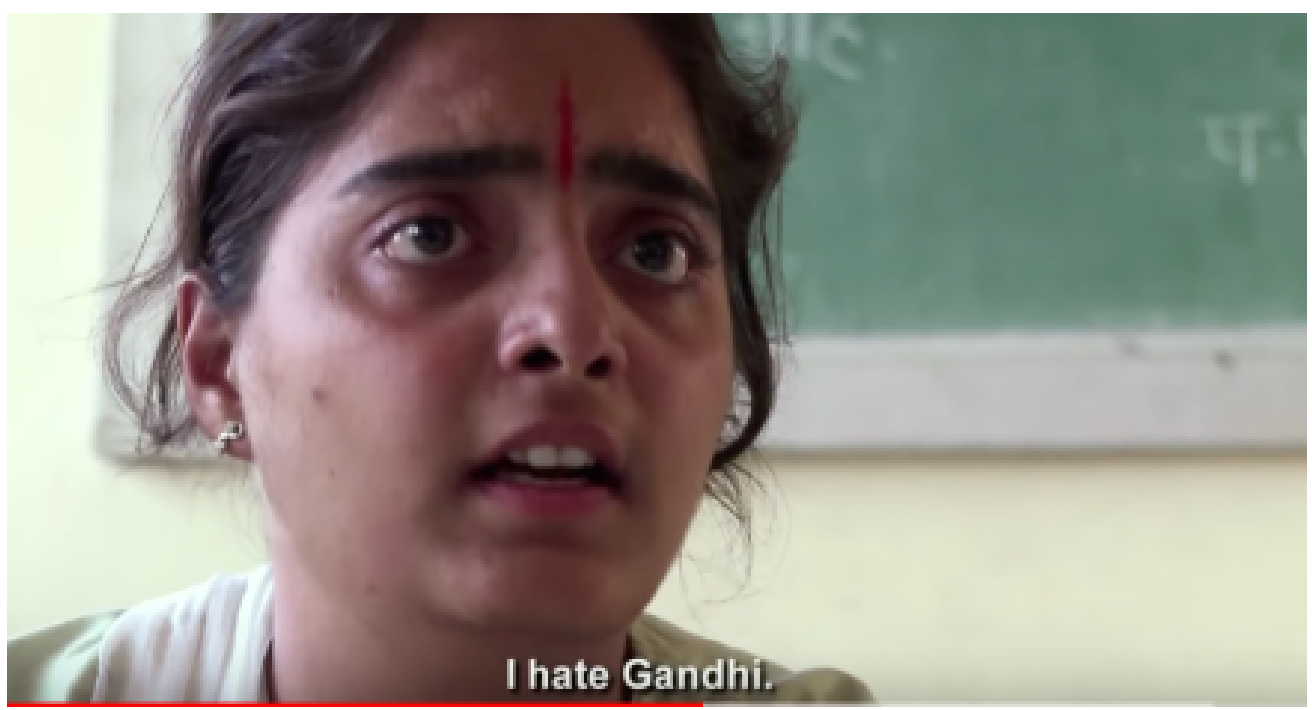

Still from the film "The World Before Her". Dir. Nisha Pahuja (2012).

Very explicitly, Prachi Trivedi expresses her distaste for what she calls "girly" things and for normative ideals of femininity, including that of marriage and motherhood. At the same time, several scenes in the film The World Before Her clearly suggest that Trivedi may herself have experienced violence in her family. Her father boasts about the fact that he used to beat his daughter "a lot" and how he once even hit her feet with a heated iron rod. Prachi Trivedi nevertheless says that she feels obliged to her father for "allowing her to live" and not killing her, even though she was "only" a daughter.

In the film, Trivedi also states that she is "different from girls ... and different from boys" and that while making her, as she says, "God was in a 'different mood' so he combined these two things and sent me down. My life is not for getting married...or to produce children ...I have a feeling I have not been made by God for these things but rather for a life dedicated to the Vishva Hindu Parishad". However, it is clear that especially her father puts her under a lot of pressure to complete her femininity by getting married and becoming a mother. At the same time, he says about his daughter: "What can be more honorable than dying for your nation... I will be the happiest person on earth if she sacrifices her life in the service of the nation" [Hussain and Hussein 2016:234]. Although Prachi Trivedi's individual beliefs around marriage and children are opposed to the ideology of the paramilitary organization that she politically subscribes to, she says towards the end of Nisha Pahuja's documentary that 
she will continue to "advise young girls to get married and have children, reproducing the nation culturally and biologically" [ibid.:236].

("Hindustan for Hindus, Pakistan go to hell is mantra at Durga Vahini camp",_ummid.com, Nov 11,2014: "Girls here are trained to be warriors and wives - they must be strong enough to break the bones of the enemy but docile enough to never question their husbands")

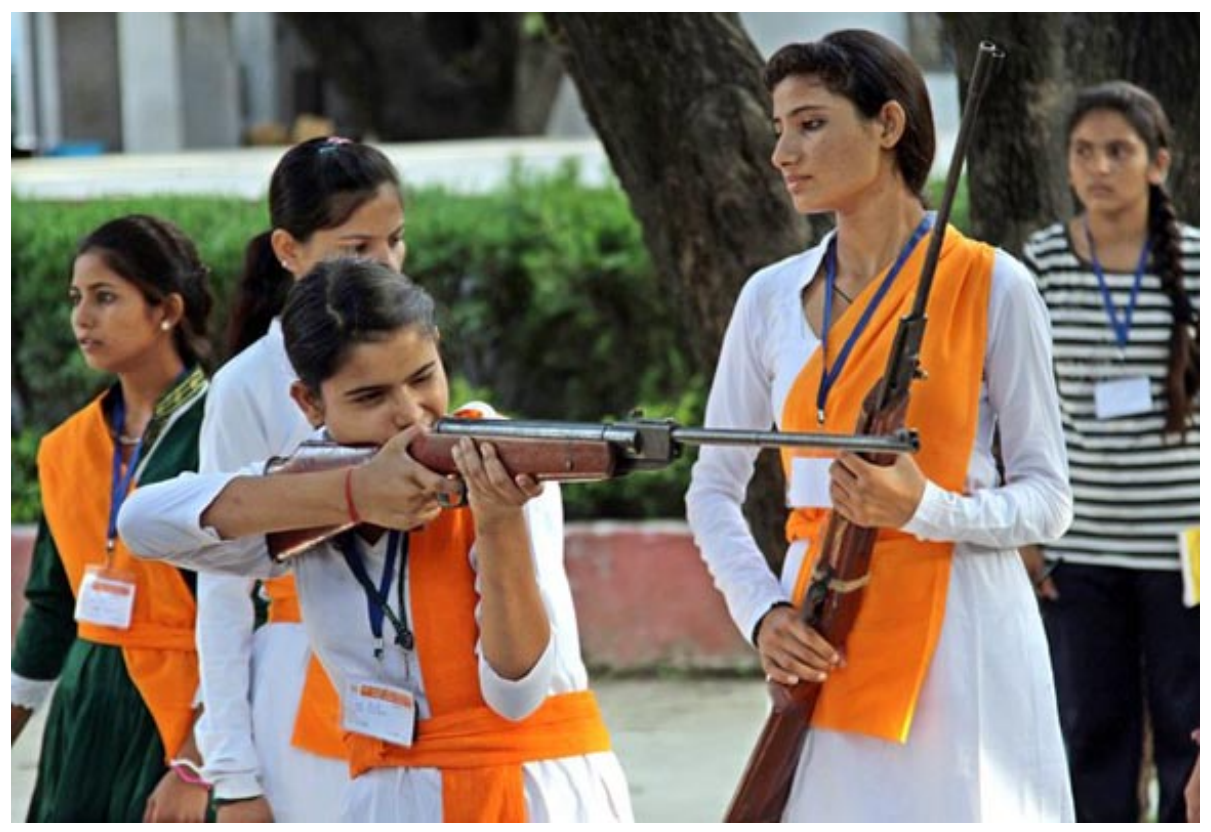

Image taken from the website www.shethepeople.tv. "Up in arms for the Hindu Nation: Durga Vahini". SAKSHI. June 24, 2016. https://www.shethepeople.tv/news/up-in-arms-for-thehindu-nation-durga-vahini/ (last checked Mar 17, 2022).

(Excerpt from the official website of the Vishva Hindu Parishad (World Hindu Council):

"Durga Vahini (...) had undauntedly faced all the obstacles in the path of reaching Ayodhya for Karsewa like their male counterparts. The blood-stained scenario in Ayodhya on that day rather forced them to forsake their normal female tenderness and affinity; and assume a most splendorous form by creating a living, sturdy women's wall around to protect their brothers who were being assaulted by the security forces with lathis and bullets. They were not deterred even after they were arrested by the police and deserted in a sort of forlorn, far away places. They walked the long-off distances on foot. (...) It is expected from the Durgas of Durga Vahini that they extend their co- 
operation in providing a solid support to the Hindu Society and culture by ending all types insecurity, unrighteousness, immorality and inequality among Hindus and to launch our nation on to the path of progress; to create a Dharmic atmosphere and to reestablish Dharma by destroying all the wicked and crooked people like Durga Devi did in the ancient times.")

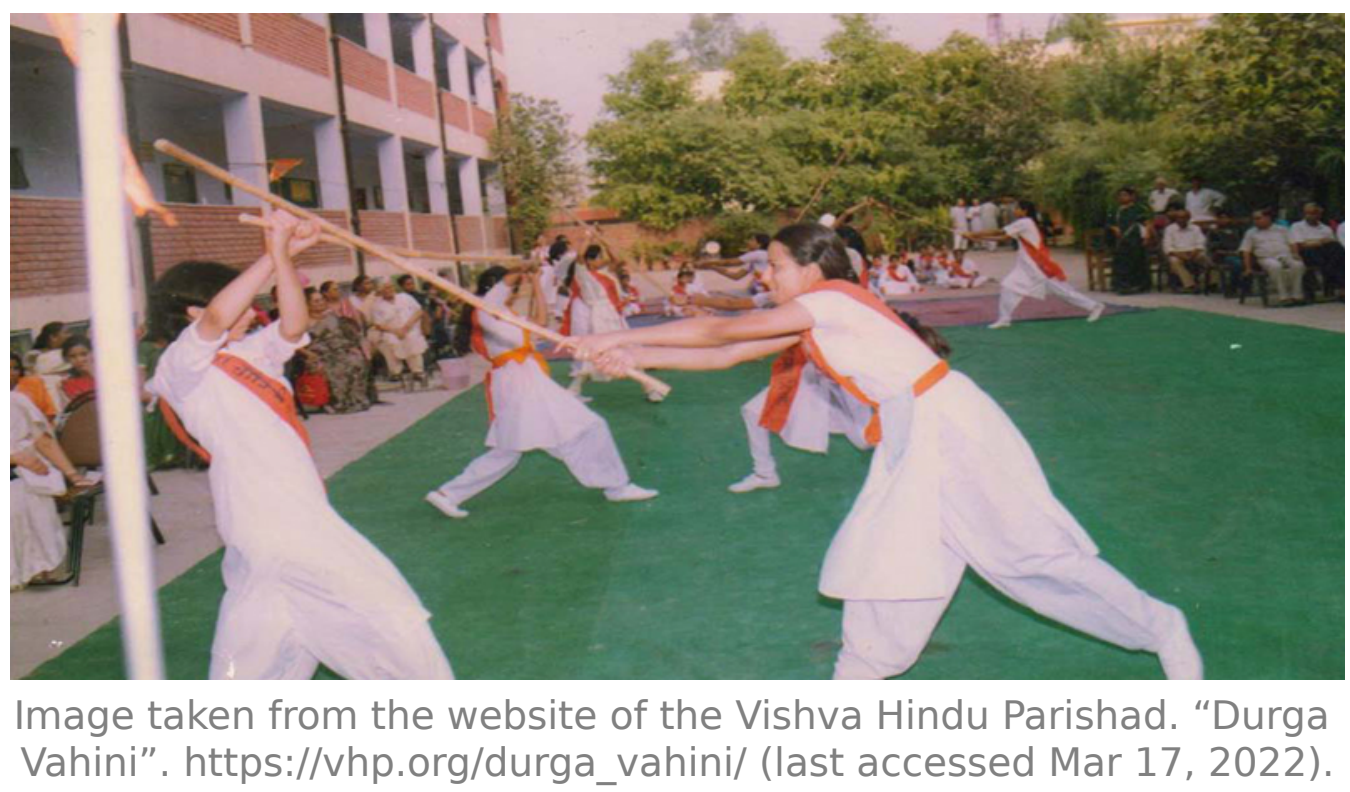

\section{From 'Mother India' to 'India's New Daughters'? Shifting focus on young women and their status in society}

Perhaps not surprisingly, this is in sync with a new focus that was laid by the (ruling) BJP on the improvement specifically of the status of young women in society who were now increasingly referred to by the party as the 'state's daughters'. Prime Minister Narendra Modi himself occasionally poses or is visually presented as the fatherly figure of a nation caring for its daughters. Since 2015, a positively connotated 'fatherdaughter-relationship' moved center-stage and became even more visible in context of the widely received hashtag campaign \#selfiewithdaughter, launched by Sunil Jaglan in the federal state of Haryana, which was endorsed by the BJP [see Titzmann 2020]. Although a National Girl Child Day had already been introduced during Manmohan 
Singh's (Indian National Congress) tenure as Prime Minister of India in 2008 (celebrated on the 24th of January), it has gained much more visibility since 2015.

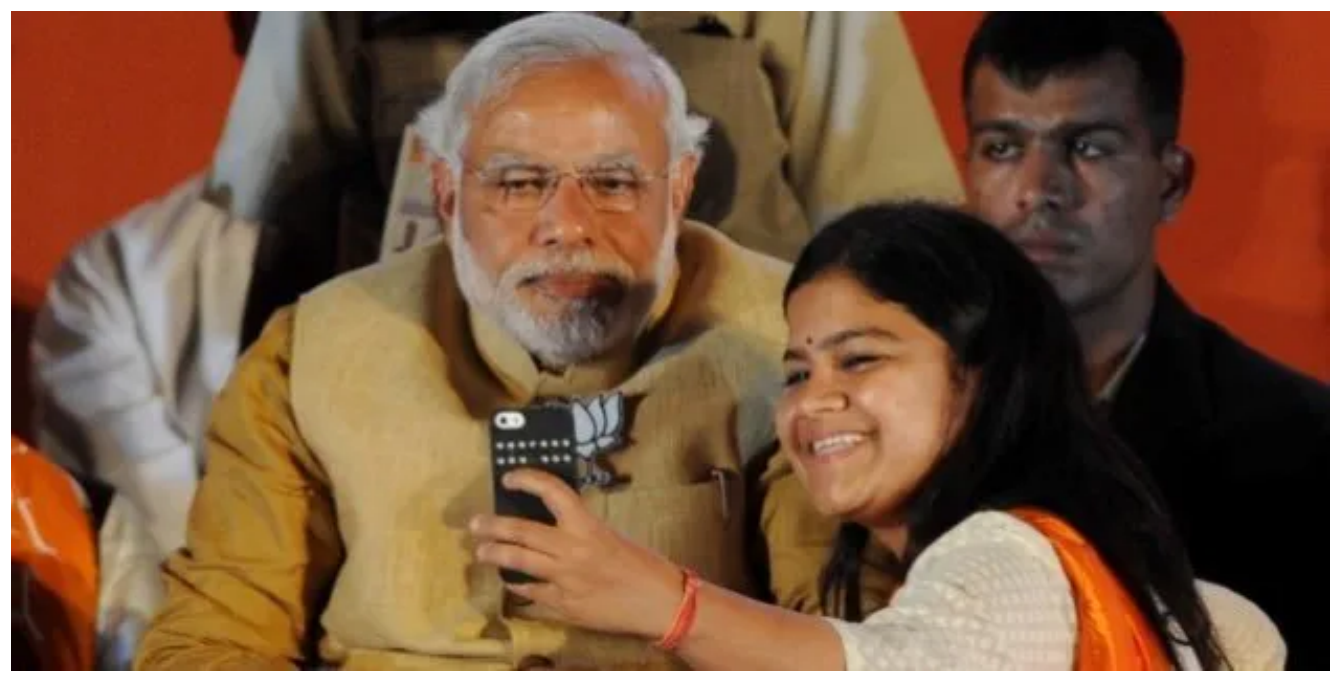

Image taken from the website of Huffpost. “Modi Announces Father-Daughter Selfie Campaign For The Girl Child", by Betwa Sharma. June 28, 2015.

https://www.huffpost.com/archive/in/entry/modi-announcesfatherdaug_n_7680494 (last accessed Mar 17, 2022). 


\begin{abstract}
Arvind Gupta @ArvindGuptaJK·24. Jan.
Pic of the day

Our daughters are our future. As we celebrate \#NationalGirlChildDay \#DeshKiBeti
\end{abstract}

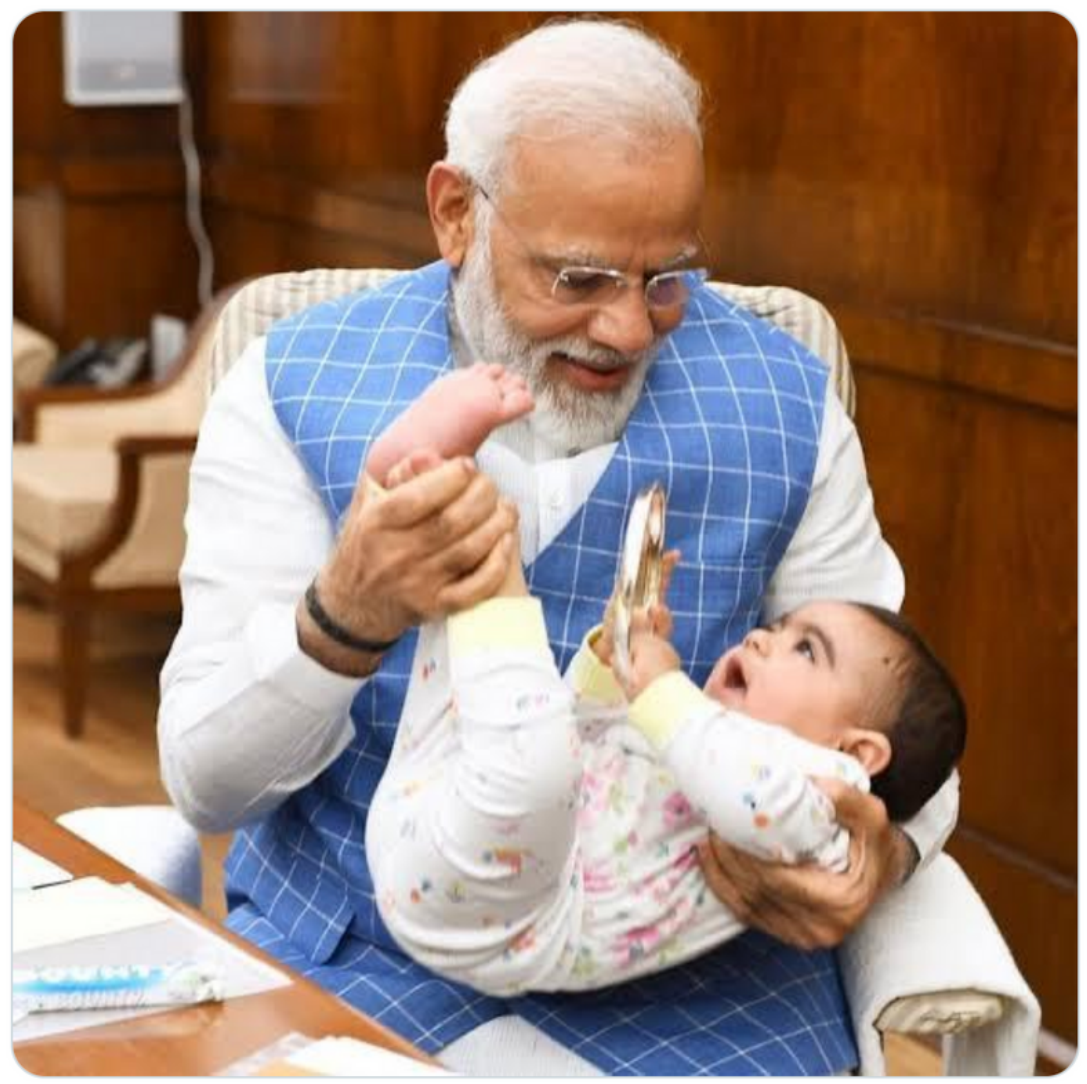

\title{
Image taken from the Twitter page of Arvind Gupta, Jammu and Kashmir BJP Secretary.
}

In the \#selfiewithdaughter campaign, the unmarried young woman is obviously never represented or addressed as a an individual. However, it is interesting to note the ideological shift or perhaps the ideological differentiation here, since the 'survival' of the imagined national community no longer depends solely on the role and relationship of mothers and sons. Since 2015, it rather seems that 'India's new daughters' are strategically placed at the center of a national narrative of future-oriented development, global competitiveness, and modernity. As Deepra Dandekar has noted, the way the BJP uses the label "India's daughters" today is quite different from the meaning it had acquired in the context of the partition of the Indian subcontinent in 1947 when the Indian state retrieved Hindu and Sikh women from Pakistan who had been abducted during the mass migration from as well as to the newly founded states 
of India and Pakistan [Dandekar 2021]. Against the background of an ongoing debate about gender-based discrimination, violence as well as rampant female feticide in several Indian states, but also a general climate which is perceived as extremely hostile towards women [see John, Kaur et al. 2009; Atwal and Flessenkämper 2020; Schneider and Titzmann 2014], the BJP sought to address these issues and positively influence the immediate living conditions and to win the trust of girls and young women in the country. $\underline{7}$

Although it is rarely mentioned explicitly, the new strong focus on young women can also be related to the repeatedly formulated demand brought forward by the economic sector to increase the number of women in the formal workforce. Especially through their jobs in the service industries, notably the IT or Call Center industries, many young women contribute significantly to the family income - but at the same time, their work and lifestyle has often been viewed with suspicion, especially if they were working the nightshift [see Patel 2010]. By officially endorsing young women's professional activity and employment, the government thus opens up a new perspective for the upward social mobility of entire families who invest in their daughter's education or vocational training, and they also give them the possibility to be proud and to publicly share their pride in their daughter's professional achievements and careers. Essentially, however, contemporary discourses and visual representations of India's 'new daughters' are conceptualized in a family-centered rhetoric and a framework of a nationally loaded symbolism.

After the landslide victory of the BJP in the 2019 federal election and second term of Prime Minister Narendra Modi, the noticeable attempt by the government to portray India as a "nation in which women's empowerment has been imbibed in our culture for centuries"[Singh 2020] continues.

\section{Ambiguous empowerment: Redefinition of 'Nari Shakti' as integral to 'Rashtra Shakti'}

When 26-year old Captain Tania Shergill led an all-men marching contingent of the Corps of Signals in the $71^{\text {st }}$ Republic Day Parade in January 2020, she was celebrated as a new symbol of India's Nari Shakti ("woman power"). Soon after yet another 'historic display of women power' was over, however, Indian news media reported on a "raging debate" about combat roles for women in the Indian army as well as existing reservations on giving command positions and permanent commission to women in the 
Indian Armed Forces. Especially the question of women in frontline combat roles continues to be a contentious issue, notably in the Indian army, whereas the doors 'have been opened' for women to take on combat roles in the Indian Air Force (IAF) and Navy. This distinction is repeatedly made based on perceived physiological differences between men and women, even though it is a well-known fact that women have actively participated in India's freedom struggle and despite unmistakable statements of highly visible persons like Tania Shergill who stated in an interview if women were given a "combat role in the Indian Army, we are all up for it" [Chandani 2020].

Interestingly, women's 'decision-making power and technical intelligence' is not denied in this context, but as one senior wing commander put it in an interview with the Indian newspaper The Asian Age, "when you go directly on the battlefields, then physical efficiency is a must". In addition, male soldiers in the Indian army are allegedly "not ready to accept orders from female officers due to physiological differences" [ibid.].

Against the background of this ongoing debate about women's roles in the Indian army, an intervention made by Defence Minister Rajnath Singh on the occasion of International Women's Day in March 2020 is particularly noteworthy. While many people were still wondering what role the so-called 'weaker' section can play in the Indian Armed Forces, women officers have according to Singh already demonstrated that they are "second to none" by their unique contribution in various services and arms of the Indian forces [ $\underline{\operatorname{Sin}} \underline{\underline{h} \text { 2020] }}$. But for the current Defence Minister, this is not enough, as the "empowerment" of women in the Indian Armed Forces and significant increase in women's participation in various departments as well as field operations are a "major focus of the BJP government", as he explains [ibid.]. 


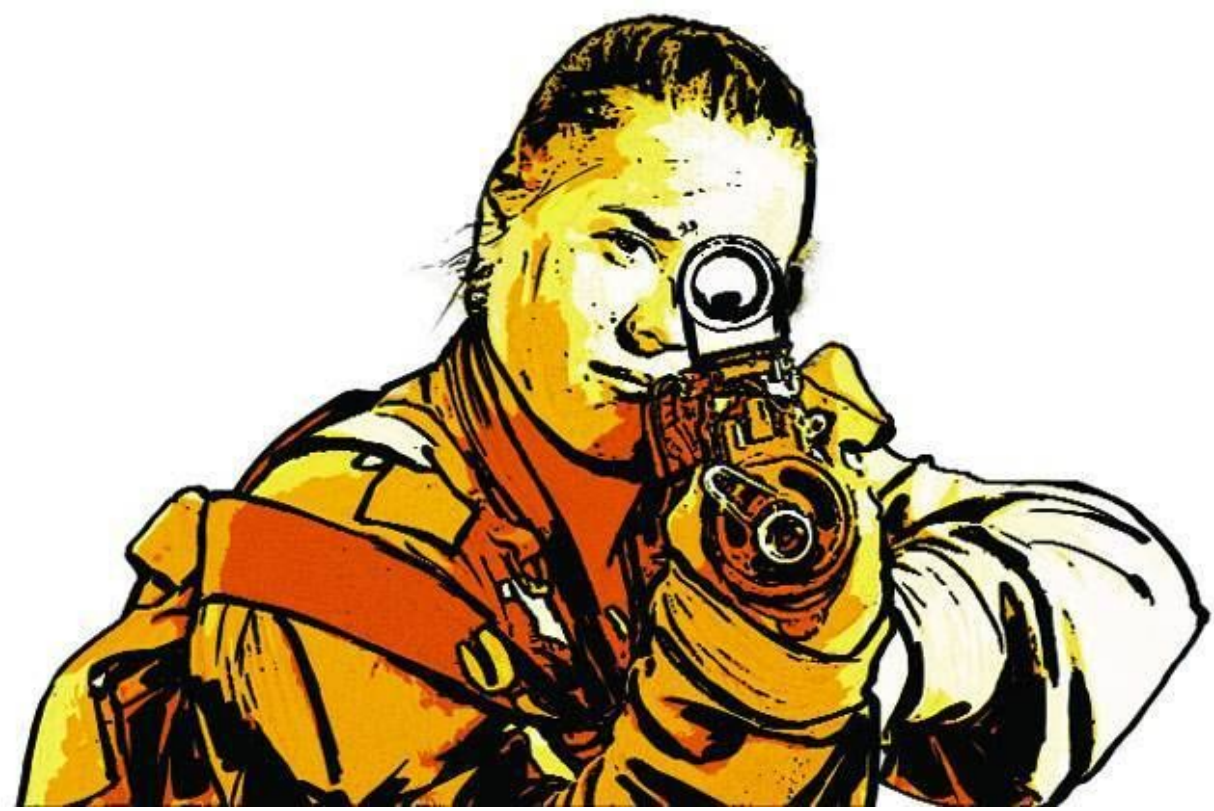

“Empowerment of women in the armed forces has been a major focus area of our government over the past five years and many interventions are first-time initiatives."

The English-language newspaper The Indian Express used this image as an illustration for Rajnath Singh's article on the occasion of International Women's Day in 2020. Mar 9, 2020. https://indianexpress.com/article/opinion/columns/international-womensday-gender-equality-rajnath-singh-girl-education-women-indian-army6305736/ (last accessed Mar 17, 2022).

In his previous role as Union Home Minister in the NDA (National Democratic Alliance) government from 2014 until 2019, Singh had already taken special efforts to increase the number of women in the police and paramilitary forces. Other steps have been taken, such as increasing the tenure of women officers in short service commissions (SSC) from 10 to 14 years and improving their promotional prospects in the army, had been taken. Another substantial increase has taken place in the enrolment and representation of girl cadets in NCC (National Cadet Corps). The BJP government has also initiated a project called Sainik Schools for girls (sainik as an adjective means "belonging to the sena", the Sanskrit and Hindi word for army). Admission of girl students in Sainik Schools started in a pilot project in the North Eastern state of Mizoram in 2018-19 and five more Sainik Schools in different parts of the country have started the enrolment procedure for the academic year 2021-22.

A new visual icon: women fighter jet pilots of the Indian Air Force 


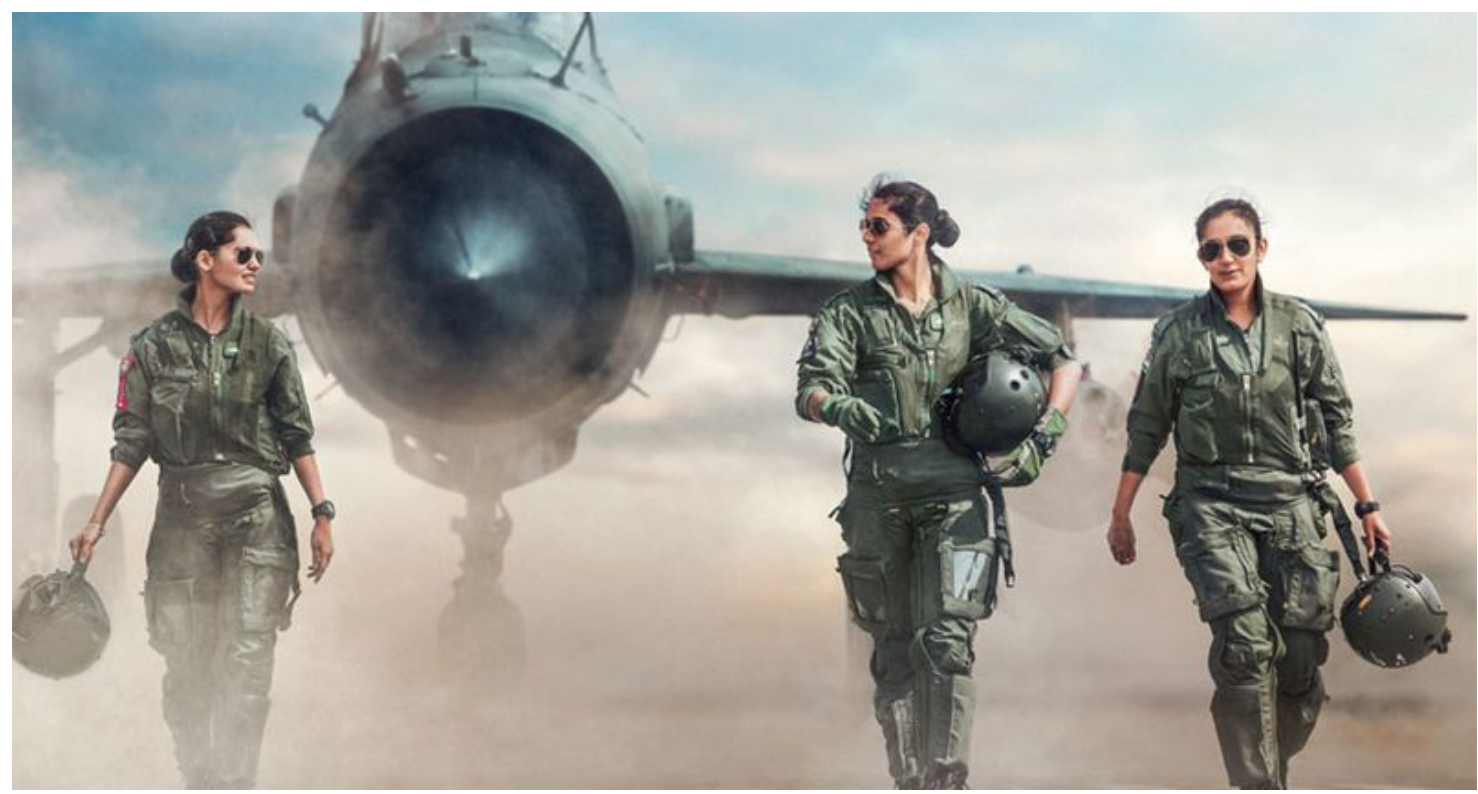

Sky's not the limit.

“The IAF has been at the forefront of empowering women. While they were always enrolled in the medical branch, in 1992 the IAF started the induction of women to other branches initially in Ground Duties, and later to train for flying transport aircrafts and helicopters as well. Even though these roles were directed towards combat support ops only, the IAF was the first defence service to do so. Today, there are around 1,500 women in the IAF. And now, it is yet again paving the path for women by enrolling them in front-line combat roles - thereby putting India on the world map." ELLE India, April,2018. https://elle.in/elle-old-site/article/indian-airforce-three-women-fighter-jet-pilots/ (last accessed Mar 17, 2022).

As this widely circulated image of the three fighter jet pilots Avani Chaturvedi, Bhawana Kanth and Mohana Singh indicates, it is especially the highly visible figure of the young female Air Force pilot that is currently emerging as a central aspirational icon in this context. The visual celebration of role models and search for more 'inspiring' narratives about women pilots in the Indian Air Force also led to the recent 'rediscovery' of Gunjan Saxena's story. 


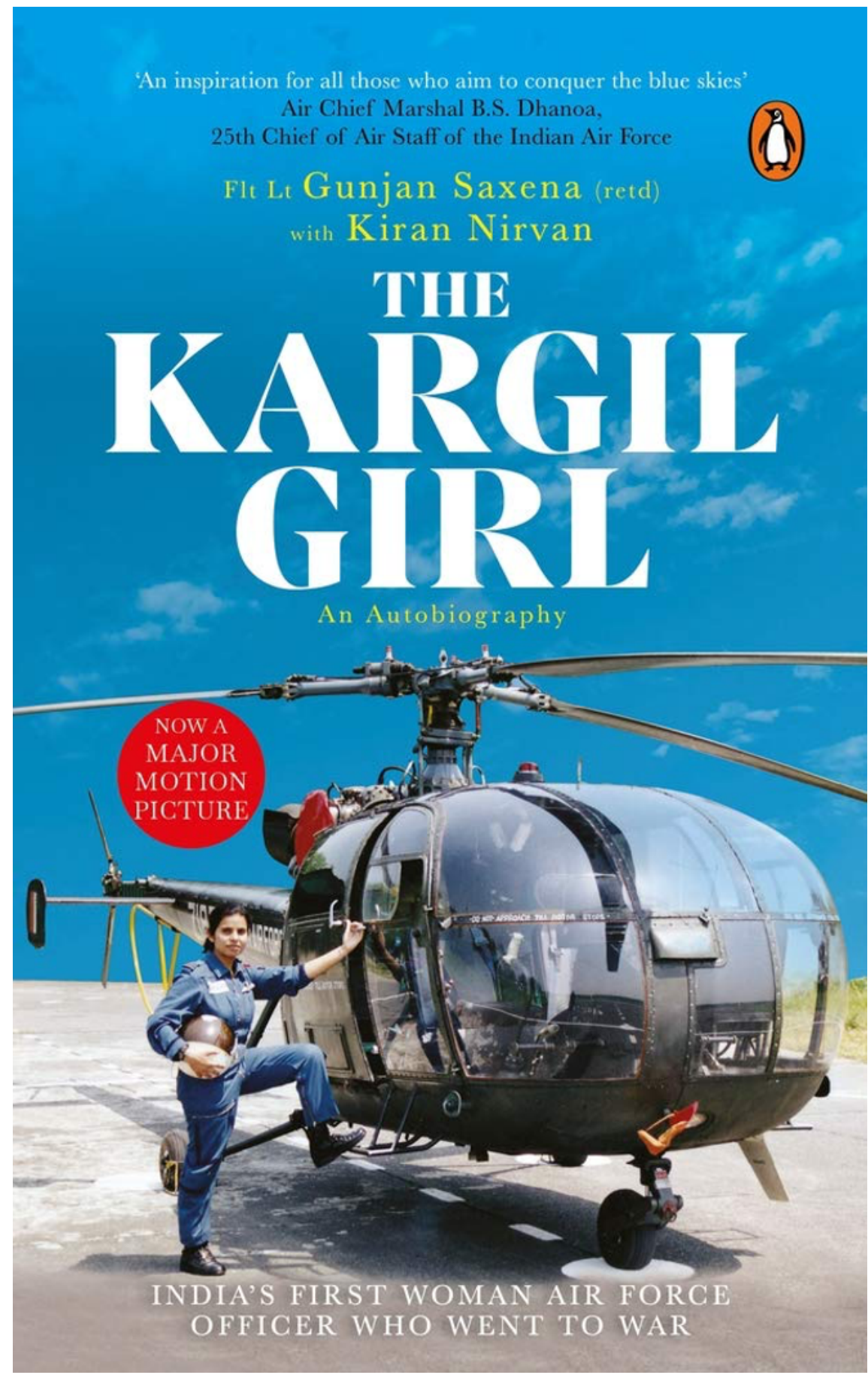

Cover image of the book taken from the website of Penguin India. https://penguin.co.in/book/the-kargil-girl/ (last accessed Mar 17, 2022)

Flight Lieutenant Gunjan Saxena was among the first batch of women to join the Indian Air Force in 1994, the year in which the female transport and helicopter pilots 
were admitted. She was also one of two female pilots who flew reconnaissance flights during the Kargil War between India and Pakistan that took place between May and July 1999 in the Kargil district of Kashmir. Saxena evacuated casualty and was also responsible for the transport of supplies and she assisted in surveillance. Her career ended in 2004, after serving as an Air Force helicopter pilot for eight years, as permanent commissions were not available for women at that time.

Saxena's autobiography titled “The Kargil Girl” was first published in August 2020 and received a lot of media attention in India. As one of the two co-authors of Saxena's autobiography, Kirandeep Singh, said in an interview with the BBC: "She's an inspiration but over the years,_people had begun to forget her achievement and it was an attempt to revive an interest in her story.". In the same month, however, a Netflix biopic titled "Gunjan Saxena: The Kargil Girl" was also released and soon raced to the top of the Netflix charts in India. The first reviews were still enthusiastic and the Times of India, one of the leading English-language newspapers in India, described the film as a "deeply moving tale of a feminist father and his feisty daughter". Saxena describes in the above-mentioned BBC article that she received "lots of messages from little girls saying that after watching the film, they too want to join the air force and become pilots". The Netflix biopic was produced by the production and distribution company Dharma Productions which was founded by Yash Johar in the 1970s and taken over by his son, the highly successful Hindi film director, producer, screenwriter, and TV anchor Karan Johar.

However, public opinion changed significantly when the Indian Air Force sent a letter expressing its disappointment to Dharma Productions, the Central Board of Film Certification (CBFC) and to Netflix, and called for a censoring and deleting of scenes which in their perception exaggerated the existing sexism and gender disparity in the IAF. Despite increasing pressure to boycott and stop the screening of the film, neither Netflix nor Dharma Productions gave in. Instead, a disclaimer was added which states that the film is a "fictionalized and dramatized version of the life events of Flight Lieutenant Gunjan Saxena" and that the "producer, director, artists or other associated with this film are all law-abiding citizens and have not created this film to incite any disorder or lawlessness".

I would like to briefly highlight two interesting aspects of this Netflix biopic. First, the strong focus on the father-daughter relationship and seemingly unrestricted support of a 'feminist' father for his ambitious daughter. This stands in complete contradiction to the mother and brother who are almost peripheral figures in the depicted family; the 
mother doesn't understand her daughter's ambition to become a pilot and seems to be stuck in a patriarchal mindset . So is Gunjan's conservative brother in the film who is rebuked by their father when he deploys a rather clumsy rhetoric of gendered safety to convince him that he should restrict his daughter's mobility and prioritize her physical security vis-à-vis her own strong will and ambition.

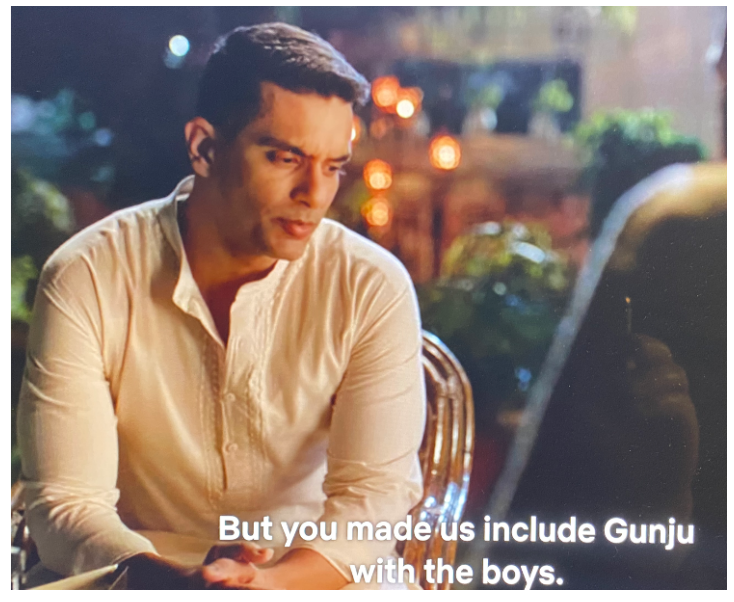

Still from the Netflix biopic "Gunjan Saxena: The Kargil Girl”. Dir. Sharan Sharma (2021).

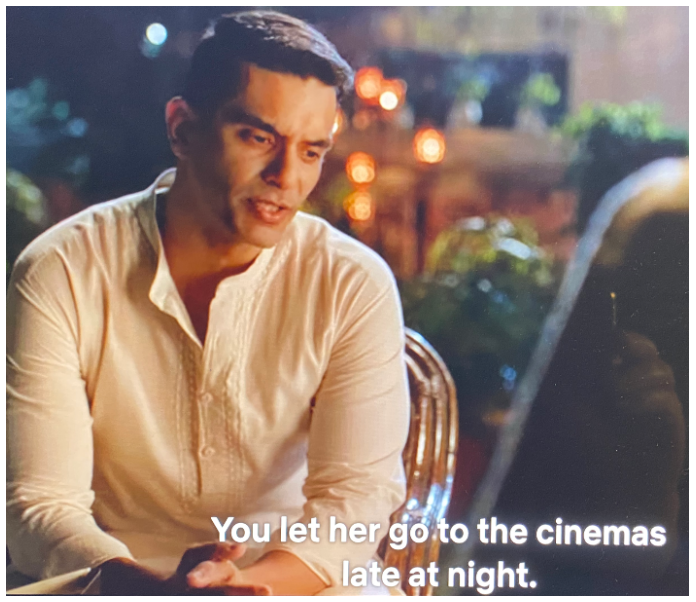

Still from the Netflix biopic

The secon "Gunjan Saxena: The Kargil Girl". Dir. Sharan Sharma (2021).

d

interesting aspect concerns the question of Gunjan's 'patriotism' and motivation to join the Indian Air Force. During one scene of the film, Gunjan wakes her father up in the middle of the night to discuss patriotism with him. Unlike the real Gunjan Saxena, the film character talks in this scene about her joining the IAF only to pursue her dream to become a pilot, not because of her patriotism. "I'm not being a traitor to the country for my dream, am I", she asks her father, himself a former army officer, who responds to this by explaining that loudly shouting nationalist slogans is not what makes a true patriot. "Be a strong, hard-working and sincere pilot, and you'll automatically be a patriot", is his advice to his daughter. 

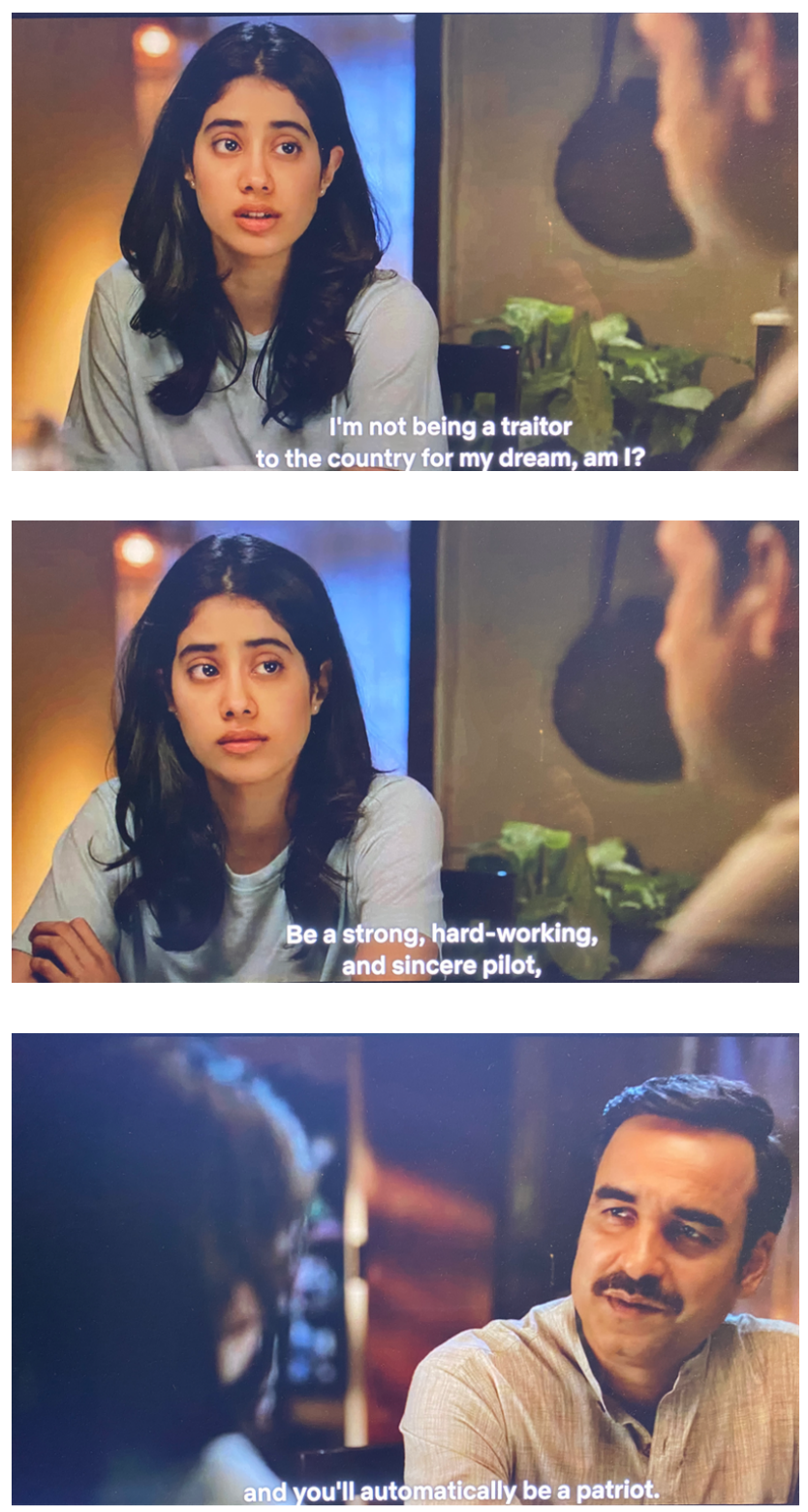

Stills from the Netflix biopic "Gunjan

Saxena: The Kargil Girl”. Dir. Sharan

Sharma (2021).

\section{Discussion}

From a feminist perspective, women's participation in military combat and commanding roles in the armed forces - a particularly contested space of patriarchy can be seen as an acceptance of their status as full and equal citizens. However, in view of the ambivalent overlap with the goals of a Hindu nationalist government that is known for a highly conservative family ideology and for its continuously active role in 
instigating and supporting violence against religious minorities and other marginalized communities in India, I think it is necessary to problematize what at a first glance seems to be merely an intersection between feminism and muscular nationalism.

Without wanting to suggest a direct link or seamless continuity between the largescale participation and training of women in the various paramilitary units of Hindu nationalist organizations on the one hand, and the BJP's plan to significantly increase the number of women in the Indian Armed Forces on the other, the juxtaposition suggests obvious interlinkages between the two projects that require further analysis and critical debate.

Even though many of the Hindu nationalist organizations share basic ideological beliefs and commitments as well as existing inter-personal connections within the wider networks of Hindutva, it would be wrong to assume that Hindu nationalism is a homogenous phenomenon in India or elsewhere in the world. There are also significant differences, power struggles and rivalries between the various big or smaller Hindu nationalist organizations and groups. A particularly interesting observation by Atreyee Sen is, for example, that the paramilitary camps which are organized by the Rashtriya Sevika Samiti continue to be highly popular among middle and upper caste/class women, whereas the Mahila Aghadi (Shiv Sena Women's Organizationi) specifically addresses lower-class and poor women [en 2019].

If the strategy followed by an organization such as Durga Vahini and prominent members like Prachi Trivedi can be understood as an attempt to "de-governmentalize the state and governmentalize the self", as Saba Hussain and Nazia Hussein suggest [Hussain and Hussein 2016:233], we can therefore consider the possibility that the BJP - as the ruling party - is now attempting to re-establish the monopoly of legitimate use of military force by the state, while at the same time creating new avenues for many more young women to join the institution of the Indian Armed Forces.

Another, perhaps more obvious intention behind this campaign can be assumed in the acceptance of (women) voters who may not necessarily sympathize with the political program of the BJP nor with aggressive Hindu nationalism in general. But they may actually perceive and believe the current government, and especially Prime Minister Modi, to be doing much more for gender equality and opportunities for young women than previous governments. In a similar vein, this may also increase the acceptance of voters who still consider the Indian Armed Forces as a central secular institution of the postcolonial nation-state that could potentially contain religion-based majoritarian nationalism. 


\section{India paves way for more women in armed forces}

(1) 8 September

$<$

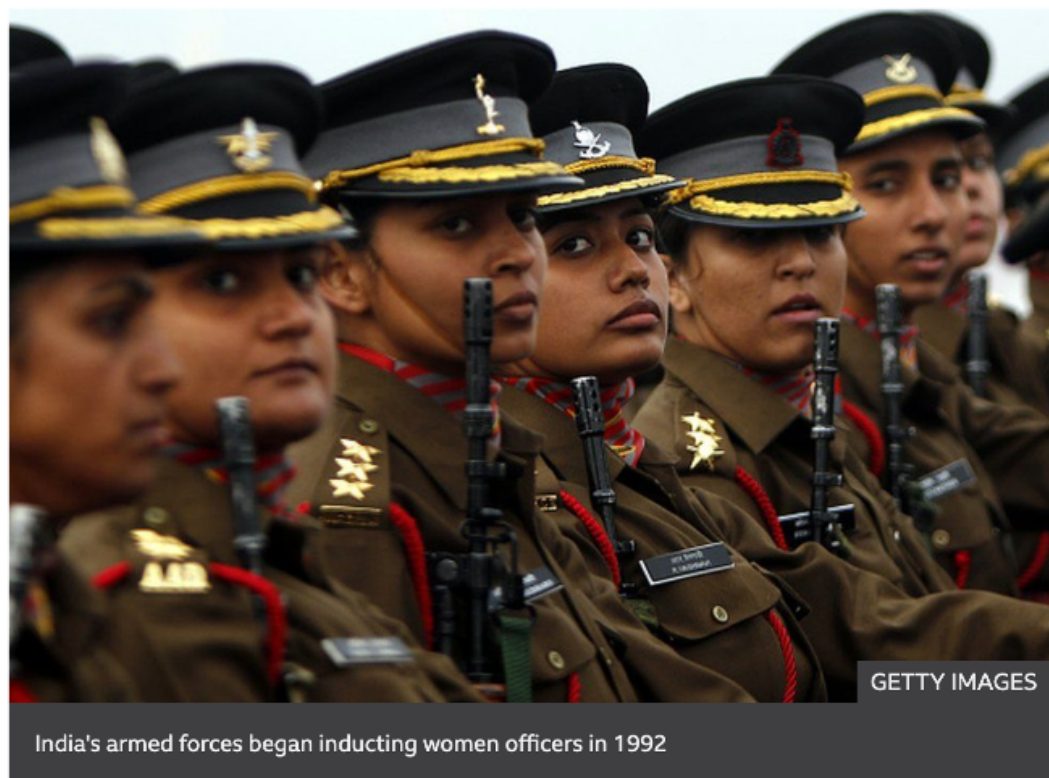

India's top court has cleared the way for more women to join the armed

India's top court has cleared the way for more women to join the armed forces.

"The armed forces play an important role... but need to do more for gender equality in the forces. We want

them to take a proactive approach themselves in ensuring gender equality rather than waiting for courts to intervene," the Supreme Court said."

https://www.bbc.com/news/world-asia-india-58486771 (last accessed Mar 17, 2022). 


\section{Elhe New Hork שimes \\ India Opens Its Highest Military Ranks to Women After Lengthy Fight}

Combat roles will still be restricted, but female soldiers and sailors will have greater access to the academy that leads to choice leadership positions.

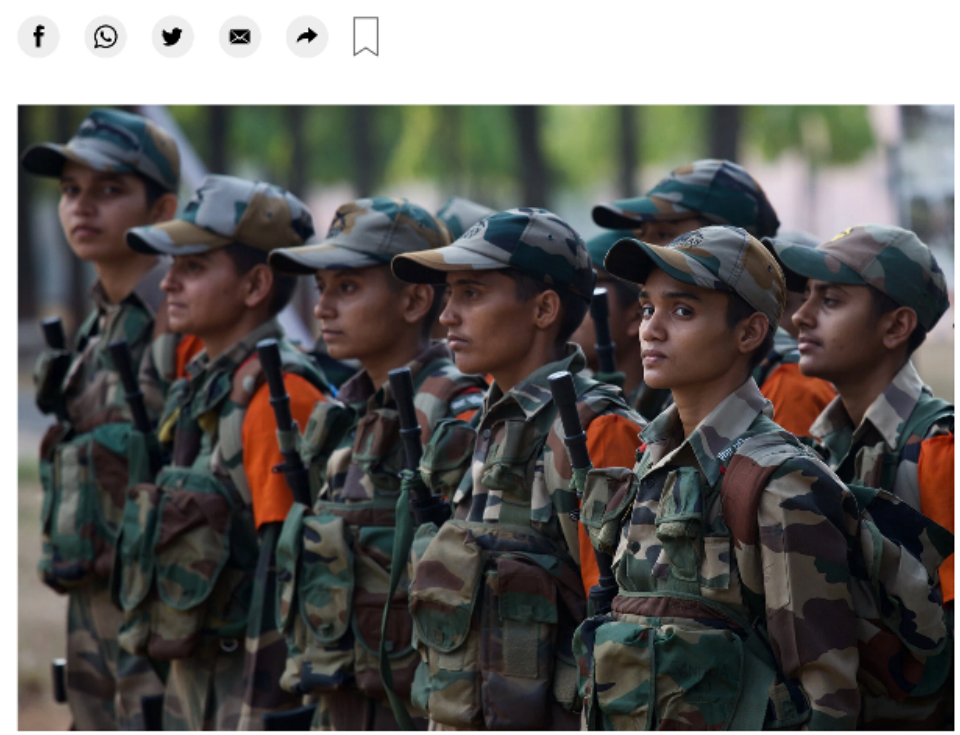

Women make up a fraction of the more than 1.3 million people serving in India's armed forces. Abhishek Chinnappa/Getty Images

\section{Screenshot taken from the website of The New York Tiimes. \\ https://www.nytimes.com/2021/09/22/world/asia/india- military-women.html (last accessed Mar 17, 2022).}

Lastly, it can also be observed currently how in the visual representation and mediation of 'India's new daughters', an analogy is drawn between the physical ability of young women to defend their own bodies as well as the borders of a national territory that is also frequently imagined and addressed as a woman or mother goddess - and equally framed as being constantly threatened by hostile 'others' within as well as outside of India, and how this is actually perceived as 'empowering' on many levels. In her ethnographic study on the politics of gendered self-defense and rightwing activism in Mumbai, Atreyee Sen provides an insightful discussion on the discourse around "Hindu women's self-defense" and the concept of swasarankshanam nari ("a woman who can protect herself"), which emphasizes the benefits of a trained 
female body [Sen 2019]. As Sen points out, many more urban women began taking selfdefense classes after the heavily medialized "Delhi Gang Rape" or "Nirbhaya Case" in 2012 and quite a few training centers were actually named after "Nirbhaya" ("Fearless"), which is not the victim's original first name but a name that was given to her after she had passed away due to the violence inflicted on her body.

Quite obviously, however, this is a limited and limiting sense of empowerment. 'Nari Shakti' is conceptualized as an integral, hence functional, or useful part of 'Rashtra Shakti', that is, the "nation-state's power", and without strengthening India's shakti, it cannot aspire to become "shaktishali Bharat", i.e. "a powerful (Hindu) India", as Defence Minister Rajnath Singh has suggested [Singh 2020].

Beyond the two hitherto available roles of the 'heroic mother' and 'celibate warrior' for women who wished to actively participate in the political project of muscular nationalism, a third role has been created in the last six years by the ruling Hindu nationalist party BJP, namely that of the (newly coined) "daughters of the state". While this may in fact create new possibilities and opportunities for many young (Hindu) women in India, it remains nevertheless firmly located in and even confirms a deeply hierarchical and heteronormative family ideology. Furthermore, to thrive, the dutiful daughter in this discursive framework always depends on the support of a father figure, either her own father or the paternalistic state, but her primary obligation always seems to be defend her individual as well as the nation's honor and thereby increase the power of the Indian nation. 


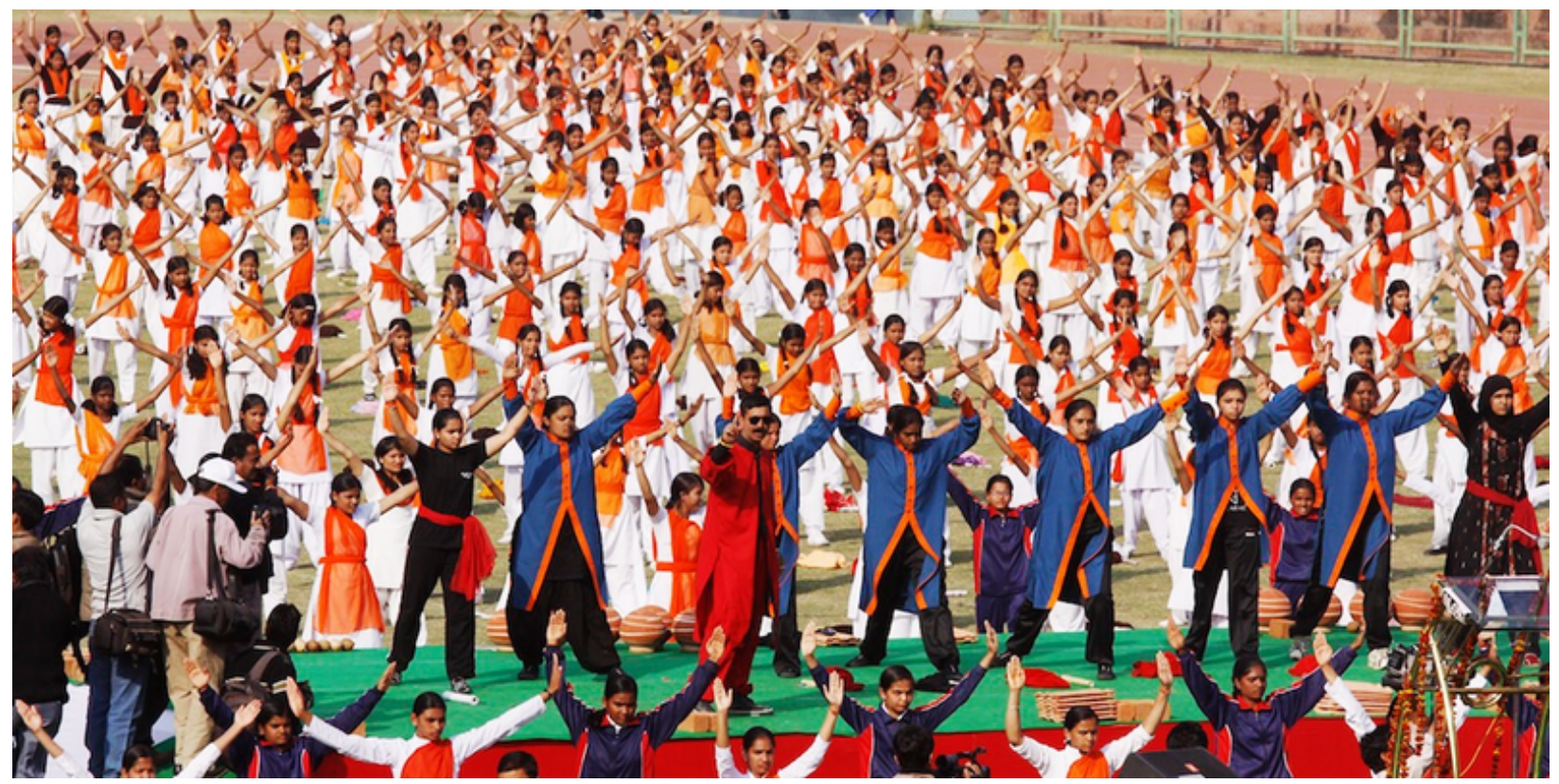

"Meet the Man who has been training Self Defence to Millions of Women across India for free", Aug 8, 2017.

Images taken from the website of Shifuji Shaurya Bharadwaj.

https://shifuji.in/tag/bengaluru-women-to-train-in-self-defense-from-worlds-bestcommando-trainer-shifuji/ (last accessed Mar 17, 2022).

Grandmaster Shifuji Shaurya Bharadwaj, as he calls himself, claimed to be an elite army officer and regularly sported combat attire. According to media reports, he was/is the "chief trainer" in ABVP's self defence programme for women. Akhil Bharatiya Vidyarthi Parishad (ABVP), the student wing of the RSS, is organising selfdefence training classes for young women across India. "Shifuji" has posted close to 500 videos on his YouTube channel "Grandmaster Shifuji's Mission Prahar" which has more than 3, 7 million followers (last checked Feb 1, 2022). 


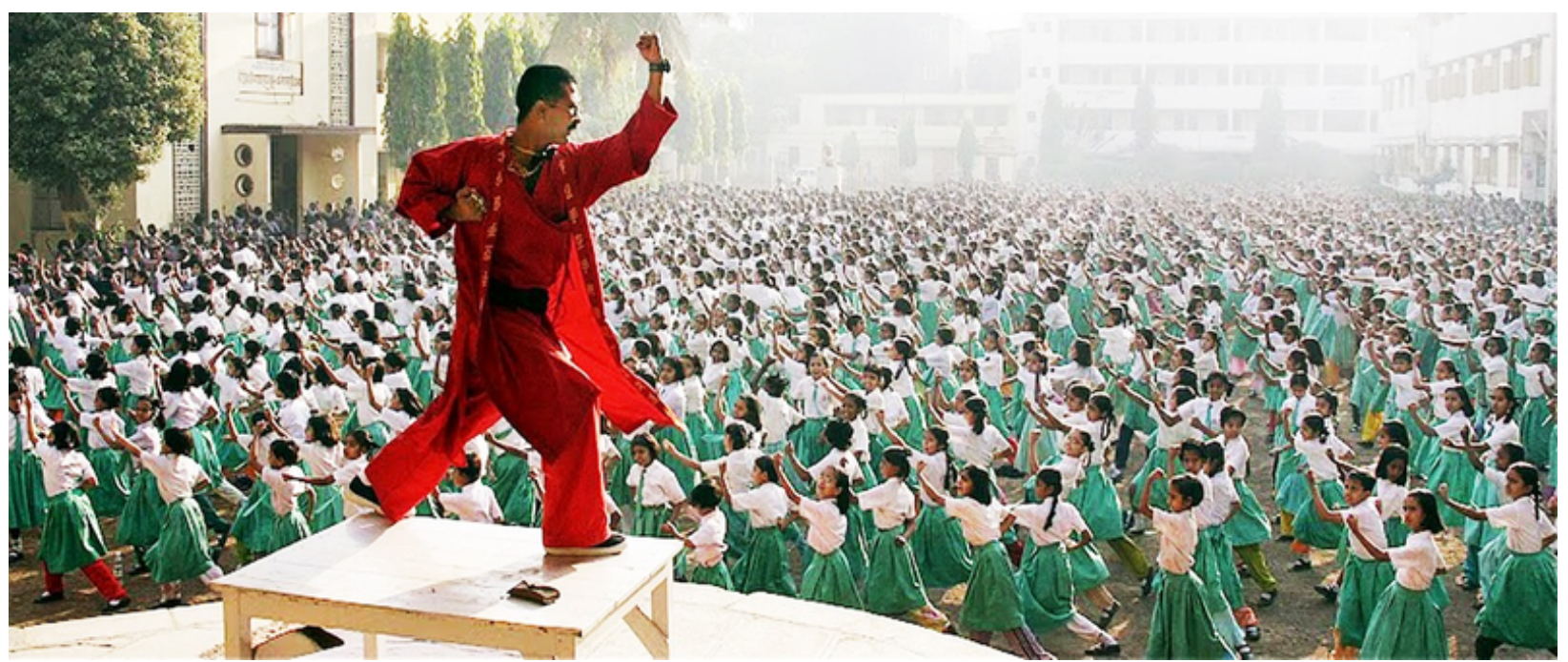

"A true patriot and a staunch lover of his Motherland, Shifuji envisions a day when India will no longer have another Nirbhaya.Through the efforts of Mission Prahar, this goal may soon become a reality."

\section{Acknowledgement}

I would like to thank several colleagues for reading and commenting on draft versions of this article: Schirin Amir-Moazami, İclal Ayşe Küçükkırca, Salma Siddique, Saskia Schäfer, Elena Schaetz and Fritzi-Marie Titzmann.

\section{Footnotes}

1. As Amy G. Mazur and Dorothy E. McBride explain, "scholars first used the term loosely to describe a range of state activities with a gender/women's issues focus. Next, the concept became associated with the study of women's policy agencies. Most recently, a group of comparative gender and policy scholars-the Research Network on Gender Politics and the State (RNGS)—has developed systematic nominal and operational definitions of state feminism to study if, how, and why women's policy agencies make alliances with women's movements within the state to achieve feminist outcomes." Mazur and McBride (2007): "State Feminism since the 1980s: From Loose Notion to Operationalized Concept". Politics \& Gender, Volume 3, Issue 4, December 2007, pp. 501 - 513. DOI:

https://doi.org/10.1017/S1743923X07000359 2. 
Monika Wohlrab-Sahr and Marian Burchardt (2012) distinguish four forms of secularity: 1) secularity for the sake of individual rights and liberties; 2) secularity for the sake of balancing/pacifying religious diversity; 3) secularity for the sake of societal/national integration and development; and 4) secularity for the sake of the independent development of functional domains of society (Wohlrab-Sahr and Burchardt (2012), "Multiple Secularities: Towards a Cultural Sociology of Secular Modernities," Comparative Sociology 11, no. 6: 889.

In the Indian context, they notice that a shift towards a concept of secularity for the sake of managing religious diversity became more apparent in the 1980s and 90s. This development was particularly influenced by the decline of state secularism as the basis for national identity and the ascendancy of the majoritarian religious nationalist narrative at the time.

However, it can be argued that the Indian Armed Forces in particular hold on to a form of secularity for the sake of societal and national integration. Not by following the idea of a strict separation "wall of separation" or "principled distance" between religion and state, but rather by 1) acknowledging religious diversity in the Armed Forces and not privileging one religion vis-à-vis others. The Sarva Dharam Sthal (common prayer hall) is of central importance to convey this idea as it 'has all the religious institutions of an army regiment in one place and under one roof'. 2) As active members of the Indian Armed Forces and veterans have made clear in recently published public appeals, they fear that a scenario in which "appointments in the Indian Armed Forces will always be based on political and religious leanings", would "signal the end of the world's finest organisation, which not only the nation but the whole world is proud of" (https://www.thecitizen.in/index.php/en/newsdetail/index/4/21439/rumblings-in-theapolitical-and-secular-armed-forces).

On the idea of 'integrative' inter faith relations and practices in the Indian army, see also "Honouring faith and secularism in the armed forces: Men who fight together must pray together" by Syed Ata Hasnain (2016) (https://timesofindia.indiatimes.com/blogs/toi-edit-page/honouring-faith-andsecularism-in-the-armed-forces-men-who-fight-together-must-pray-together/)

Needless to say, the current debate and idea of secularity in/and the Indian Armed Forces would require a paper of its own. 
3. See for instance Pankaj Mishra's article "The crisis in modern masculinity", published in The Guardian on 17 March 2018.

https://www.theguardian.com/books/2018/mar/17/the-crisis-in-modern-masculinity. 4. In the Shiv Sena's women's wing, for instance, female strength in the nation is celebrated in many of its publicly performed rituals as deriving from women's role as mothers (ibid.) $\triangleq$

5. Nisha Pahuja's documentary was released in 2012, two years before the Bharatiya Janata Party came to power as the biggest party within a coalition called the National Democratic Alliance in 2014. The film confirms the findings of other authors cited in this article that until very recently, there were no other roles available for women who wanted to participate in the ever-expanding project of muscular Hindu nationalism than those based either on the heteronormative ideal of motherhood or on the idea of a 'celibate woman warrior'. The director also launched a crowdfunding campaign (through kickstarter:

https://www.kickstarter.com/projects/411325600/the-world-before-her-indiacampaign?lang $=$ de) to finance grassroot screenings and circulations of her film throughout India. $\subseteq$

6. Although Durga Vahini has been very active in several political campaigns, compared to members of women's wings of other Hindu nationalist organizations, researchers such as Berglund mention that it is rather difficult to arrange interviews with activists of the Durga Vahini (Berglund 2009:149). See also Kovacs, Anja (2004). "You Don't Understand, We Are At War! Refashioning Durga in the Service of Hindu Nationalism". Contemporary South Asia, Vol 13, No 4, 373-388.

7. The BJP government initiated several draft bills and campaigns that can be read as measures for social change towards a family ideal based on an equal appreciation, care and support for sons and daughters alike, notably the Beti Bachao, Beti Padhao ("Save the daughter, educate the daughter") campaign. The Maternity Benefit (Amendment) Act 2017 strengthens the claim to maternal leave while a new statesponsored education programme for midwives (December 2018) aims at improving the birthing experiences of women and lower the maternal mortality rate in India (see Titzmann 2020). $\doteq$

8. There are striking parallels to other recently produced films currently streaming on Netflix, most notably perhaps "Chandigarh Kare Aashiqui" (2021). While the father shows unconditional support and love for his transgender daughter, the 
mother rejected her for years and only accepts her when the father is hospitalized and seriously ill. $\leftrightarrows$

\section{Citations}

1.

Banerjee, Sikata (2003). "Gender and Nationalism: The Masculinization of Hinduism and Female Political Participation in India”. Women's Studies International Forum, Vol. 26, No. 2, 167-179.

Banerjee, Sikata (2005). Make Me a Man!: Masculinity, Hinduism, and Nationalism in India. State University of New York Press.

Banerjee, Sikata (2010). “Women, Muscular Nationalism and Hinduism in India: Roop Kanwar and the Fire Protests". Totalitarian Movements and Political Religions. Vol 11, Issue 3-4: Gender and Political Religions, 271-287.

2.

Roy, Srirupa (2007). Beyond Belief: India and the politics of postcolonial nationalism. Duke University Press, "Politics, History, and Culture” series.

Dayan, Daniel/Katz, Elihu (1994). Media Events - The Live Broadcasting of History. Harvard University Press; Reprint Edition. $\_$

3. Mahajan, Gurpreet (2019). Unity in Diversity. Dream and Reality. Economic \& Political Weekly, Vol. 54, Issue No 5, 02 Feb.

https://www.epw.in/journal/2019/5/alternative-standpoint/unity-diversity.html 4. Banerjee, Sikata (2005). Make Me a Man!: Masculinity, Hinduism, and Nationalism in India. State University of New York Press. $\Xi$

5. Berglund, Henrik (2009). “Gender Relations and Democracy: The Conflict between Hindu Nationalist and Secular Forces in Indian Civil Society". Nationalism and Ethnic Politics, Vol. 15, No. 2, 141-159.

6. Banerjee, Sikata (2003). "Gender and Nationalism: The Masculinization of Hinduism and Female Political Participation in India”. Women's Studies International Forum, Vol. 26, No. 2, 167-179.

7. 
Sarkar, Tanika (1999). “Pragmatics of the Hindu Right - Politics of Women's Organizations". Economic and Political Weekly (31 July 1999), 2159-2167.

Basu, Amrita (1999). "Women's Activism and the Vicissitudes of Hindu Nationalism". Journal of Women's History, Vol. 10, No. 4, 104-124.

Sarkar, Tanika/ Butalia, Urvashi (eds.)(1995). Women and the Hindu Right: A Collection of Essays. Delhi: Kali for Women.

Banerjee, Sikata (2003). “Gender and Nationalism: The Masculinization of Hinduism and Female Political Participation in India”. Women's Studies International Forum, Vol. 26, No. 2, 167-179.

Sen, Atreyee (2019). “'Teach Your Girls to Stab, Not Sing': Right-Wing Activism, Public Knife Distribution, and the Politics of Gendered Self-Defense in Mumbai, India”. Signs: Journal of Women in Culture and Society, Vol. 44, no. 3, 743-770.• 8. Rai, Rajani (1996). Life Sketch of Vandaniya Mausiji: Founder and Chief of Rastra Sevika Samiti. Nagpur: Sevika Prakashan, p. 45. Quoted in Banerjee 2003: 177. 9.

Basu, Amrita (1999). "Women's Activism and the Vicissitudes of Hindu Nationalism". Journal of Women's History, Vol. 10, No. 4, 104-124.

Sarkar, Tanika/ Butalia, Urvashi (eds.)(1995). Women and the Hindu Right: A Collection of Essays. Delhi: Kali for Women. $\bullet$ 10. Hussain, Saba and Hussein, Nazia (2016). "Beauty Queens and Hindu Militants: Indian Women's Negotiation with Neoliberalism and Hindu Nationalism". Exchanges: The Warwick Research Journal 3 (2), 227-240.

11. ibid.: $236 . \triangleq$

12. see Titzmann, Fritzi-Marie (2020). "Reframing Indian Fatherhood: Manhood, Responsibility and Patriarchal Hegemony". In: Schneider, Nadja-Christina/Titzmann, Fritzi-Marie (eds.). Family Norms and Images in Transition. Contemporary Negotiations of Reproductive Labor, Love and Relationships in India. Baden-Baden: Nomos, pp. 11-31.

13. Dandekar, Deepra (2021). “Women's 'Retrieval' from Pakistan: 'India's Daughters' and the Emotional History of Partition”. South Asia: Journal of South Asian Studies. 
44:4, 703-720. $\subseteq$

14.

See John, Mary/ Kaur, Ravinder et al. (2009). "Dispensing with Daughters:

Technology, Society, Economy in North India." Economic \& Political Weekly 46(15):

16-19.

Atwal, Jyoti/ Flessenkämper, Iris (eds.) (2020). Gender and Violence in Historical and Contemporary Perspectives: Situating India. London \& New York: Routledge.

Schneider, Nadja-Christina/ Titzmann, Fritzi-Marie (eds.)(2014). Studying Youth, Media and Gender in Post-Lib-eralization India: Focus on Sexual Violence, New (Im)Mobilities and Evolving Gender Identities. Berlin: Frank \& Timme. $\triangleq$ 15. see Patel, Reena. (2010). Working the Night Shift. Women in India's Call Center Industry. Stanford University Press. $\bullet$

16. Singh, Rajnath (2020). More power to her: 'Stree shakti' is an integral part of our 'rashtra shakti'. Indian Express, March 9.

https://indianexpress.com/article/opinion/columns/international-womens-day=genderequality-rajnath-singh-girl-education-women-indian-army-6305736/

17. Chandani, Priyanka (2020). "A force to reckon with". The Asian Age, March 22. 18. Singh, Rajnath (2020). "More power to her: 'Stree shakti' is an integral part of our 'rashtra shakti'. March 9, Indian Express online. https://indianexpress.com/article/opinion/columns/international-womens-day=genderequality-rajnath-singh-girl-education-women-indian-army-6305736/

19. Singh, Rajnath (2020). "More power to her: 'Stree shakti' is an integral part of our 'rashtra shakti'. March 9, Indian Express online. https://indianexpress.com/article/opinion/columns/international-womens-day-genderequality-rajnath-singh-girl-education-women-indian-army-6305736 20. Atreyee Sen (2019). “'Teach Your Girls to Stab, Not Sing': Right-Wing Activism, Public Knife Distribution, and the Politics of Gendered Self-Defense in Mumbai, India”. Signs: Journal of Women in Culture and Society, Vol. 44, no. 3, 743-770. 21. Hussain, Saba and Hussein, Nazia (2016). "Beauty Queens and Hindu Militants: Indian Women's Negotiation with Neoliberalism and Hindu Nationalism". Exchanges: the Warwick Research Journal 20163 (2), 227-240. 
22. Sen, Atreyee (2019). “'Teach Your Girls to Stab, Not Sing': Right-Wing Activism, Public Knife Distribution, and the Politics of Gendered Self-Defense in Mumbai, India”. Signs: Journal of Women in Culture and Society, Vol. 44, no. 3, 743-770. 